Prepared in cooperation with Yale University

\title{
Preliminary Investigation of the Effects of Sea-Level Rise on Groundwater Levels in New Haven, Connecticut
}

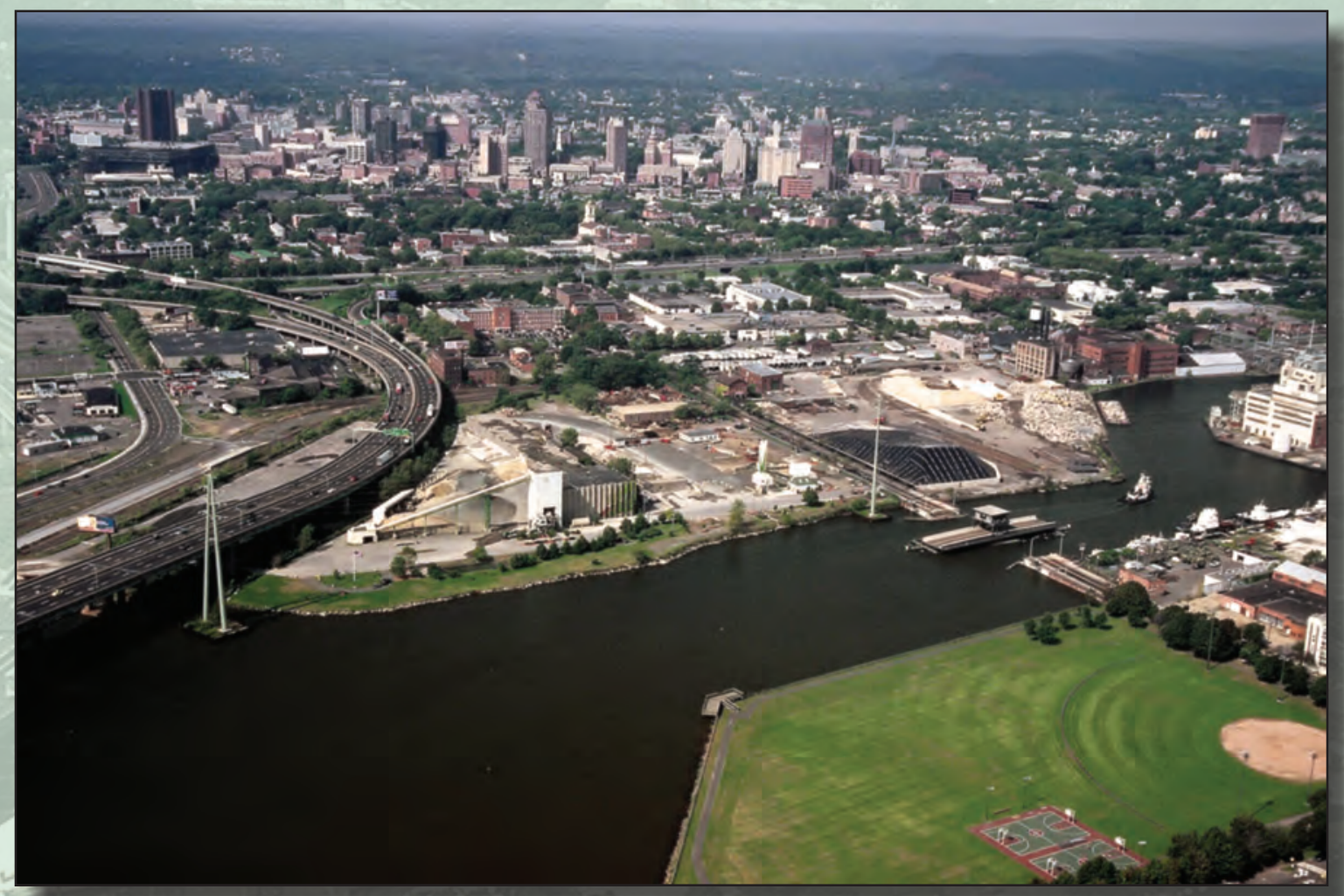

Open-File Report 2012-1025

U.S. Department of the Interior

U.S. Geological Survey 
Cover. Photograph of New Haven, Connecticut, from the mouth of the Mill River, 2003, courtesy of the Department of Energy and Environmental Protection (DEEP), Bureau of Water Protection and Land Reuse (WPLR), and the Office of Long Island Sound Programs (OLISP). 


\section{Preliminary Investigation of the Effects of Sea-Level Rise on Groundwater Levels in New Haven, Connecticut}

By David M. Bjerklie, John R. Mullaney, Janet R. Stone, Brian J. Skinner, and Matthew A. Ramlow

Prepared in cooperation with Yale University

Open-File Report 2012-1025 


\title{
U.S. Department of the Interior \\ KEN SALAZAR, Secretary \\ U.S. Geological Survey \\ Marcia K. McNutt, Director
}

\author{
U.S. Geological Survey, Reston, Virginia: 2012
}

For more information on the USGS - the Federal source for science about the Earth, its natural and living resources, natural hazards, and the environment, visit http://www.usgs.gov or call 1-888-ASK-USGS.

For an overview of USGS information products, including maps, imagery, and publications, visit http://www.usgs.gov/pubprod

To order this and other USGS information products, visit http://store.usgs.gov

Any use of trade, product, or firm names is for descriptive purposes only and does not imply endorsement by the U.S. Government.

Although this report is in the public domain, permission must be secured from the individual copyright owners to reproduce any copyrighted materials contained within this report.

Suggested citation:

Bjerklie, D.M., Mullaney, J.R., Stone, J.R., Skinner, B.J., and Ramlow, M.A., 2012, Preliminary investigation of the effects of sea-level rise on groundwater levels in New Haven, Connecticut: U.S. Geological Survey Open-File Report 2012-1025, 46 p., at http://pubs.usgs.gov/of/2012/1025/. 


\section{Contents}

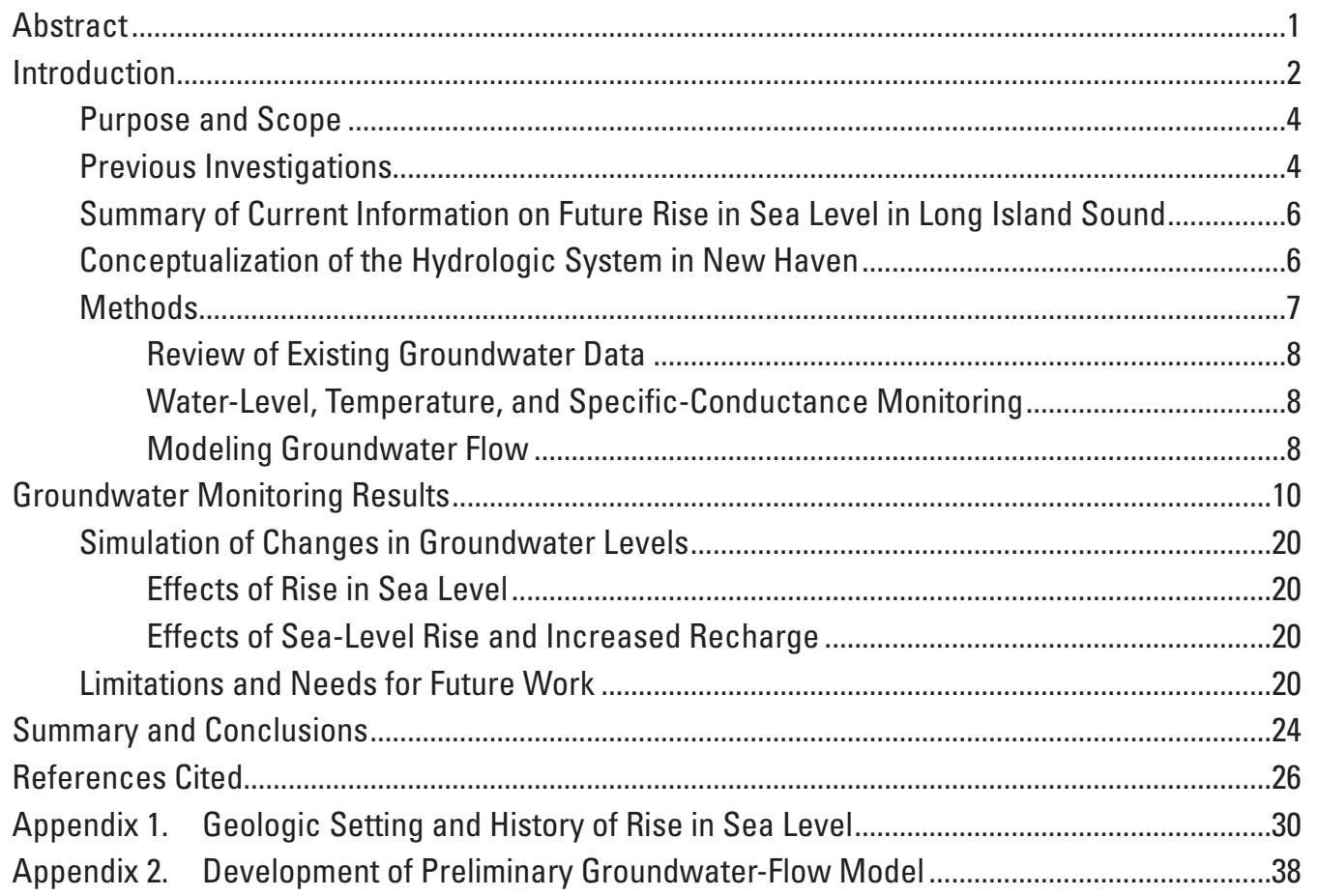

\section{Figures}

1. Map showing study area, New Haven, Connecticut.

2. Scatterplot showing water levels in observation well NHN235, New Haven, Connecticut, 1940-75.

3. Cross section showing groundwater-flow patterns and interface between freshwater and saltwater in an idealized coastal aquifer ................................................

4. Graph showing change in sea level at Bridgeport, Connecticut, 1964-2010 ..................7

5. Graphs showing groundwater-level fluctuation $A$, and groundwater temperature fluctuation $B$, for the period December 2009 to August 2010 in the continuous monitoring wells, New Haven, Connecticut.

6. Graphs showing groundwater-level fluctuation in relation to streamflow in the Mill River for the eight $(A-H)$ continuously monitored wells in New Haven, Connecticut, for the period December 2009 to August 2010.

7. Graphs showing $(A-H)$ groundwater and temperature fluctuations in continuously monitored wells, New Haven, Connecticut, for the period December 2009 to August 2010.

8. Map showing difference in groundwater levels between steady-state simulations for current conditions, and assuming a 3 -foot rise in sea level.

9. Map showing difference in groundwater levels between steady-state simulations for current conditions and assuming a 3 -foot rise in sea level and a 12-percent increase in groundwater recharge to glacial stratified deposits.

10. Graph showing simulated and mean measured hydraulic head 2009-2010, New Haven, Connecticut. 


\section{Table}

1. Monitoring wells used in this study and mean values of groundwater specific conductance, temperature, and water surface altitude..

\section{Conversion Factors, Datum, and Abbreviations}

Inch/Pound to SI

\begin{tabular}{|c|c|c|}
\hline Multiply & By & To obtain \\
\hline \multicolumn{3}{|c|}{ Length } \\
\hline inch (in.) & 2.54 & centimeter $(\mathrm{cm})$ \\
\hline inch (in.) & 25.4 & millimeter $(\mathrm{mm})$ \\
\hline foot (ft) & 0.3048 & meter $(\mathrm{m})$ \\
\hline foot $(\mathrm{ft})$ & 304.8 & millimeter $(\mathrm{mm})$ \\
\hline mile (mi) & 1.609 & kilometer $(\mathrm{km})$ \\
\hline mile, nautical (nmi) & 1.852 & kilometer $(\mathrm{km})$ \\
\hline \multicolumn{3}{|c|}{ Area } \\
\hline square foot $\left(\mathrm{ft}^{2}\right)$ & 929.0 & square centimeter $\left(\mathrm{cm}^{2}\right)$ \\
\hline square foot $\left(\mathrm{ft}^{2}\right)$ & 0.09290 & square meter $\left(\mathrm{m}^{2}\right)$ \\
\hline square mile $\left(\mathrm{mi}^{2}\right)$ & 2.590 & square kilometer $\left(\mathrm{km}^{2}\right)$ \\
\hline \multicolumn{3}{|c|}{ Volume } \\
\hline gallon (gal) & 3.785 & liter $(\mathrm{L})$ \\
\hline gallon (gal) & 0.003785 & cubic meter $\left(\mathrm{m}^{3}\right)$ \\
\hline gallon (gal) & 3.785 & cubic decimeter $\left(\mathrm{dm}^{3}\right)$ \\
\hline million gallons (Mgal) & 3,785 & cubic meter $\left(\mathrm{m}^{3}\right)$ \\
\hline cubic foot $\left(\mathrm{ft}^{3}\right)$ & 28.32 & cubic decimeter $\left(\mathrm{dm}^{3}\right)$ \\
\hline cubic foot $\left(\mathrm{ft}^{3}\right)$ & 0.02832 & cubic meter $\left(\mathrm{m}^{3}\right)$ \\
\hline \multicolumn{3}{|c|}{ Flow rate } \\
\hline foot per day (ft/d) & 0.3048 & meter per day $(\mathrm{m} / \mathrm{d})$ \\
\hline cubic foot per second $\left(\mathrm{ft}^{3} / \mathrm{s}\right)$ & 0.02832 & cubic meter per second $\left(\mathrm{m}^{3} / \mathrm{s}\right)$ \\
\hline cubic foot per day $\left(\mathrm{ft}^{3} / \mathrm{d}\right)$ & 0.02832 & cubic meter per day $\left(\mathrm{m}^{3} / \mathrm{d}\right)$ \\
\hline gallon per day (gal/d) & 0.003785 & cubic meter per day $\left(\mathrm{m}^{3} / \mathrm{d}\right)$ \\
\hline million gallons per day (Mgal/d) & 0.04381 & cubic meter per second $\left(\mathrm{m}^{3} / \mathrm{s}\right)$ \\
\hline inch per year (in/yr) & 25.4 & millimeter per year (mm/yr) \\
\hline \multicolumn{3}{|c|}{ Hydraulic conductivity } \\
\hline foot per day (ft/d) & 0.3048 & meter per day $(\mathrm{m} / \mathrm{d})$ \\
\hline \multicolumn{3}{|c|}{ Transmissivity* } \\
\hline foot squared per day $\left(\mathrm{ft}^{2} / \mathrm{d}\right)$ & 0.09290 & meter squared per day $\left(\mathrm{m}^{2} / \mathrm{d}\right)$ \\
\hline
\end{tabular}

Temperature in degrees Celsius $\left({ }^{\circ} \mathrm{C}\right)$ may be converted to degrees Fahrenheit $\left({ }^{\circ} \mathrm{F}\right)$ as follows:

$$
{ }^{\circ} \mathrm{F}=\left(1.8 x^{\circ} \mathrm{C}\right)+32
$$

Temperature in degrees Fahrenheit $\left({ }^{\circ} \mathrm{F}\right)$ may be converted to degrees Celsius $\left({ }^{\circ} \mathrm{C}\right)$ as follows: 
Vertical coordinate information is referenced to the North American Vertical Datum of 1929 (NGVD 29).

Horizontal coordinate information is referenced to the North American Datum of 1983 (NAD 83). Altitude, as used in this report, refers to distance above the vertical datum.

Specific conductance is given in microsiemens per centimeter at 25 degrees Celsius $(\mu \mathrm{S} / \mathrm{cm}$ at $\left.25^{\circ} \mathrm{C}\right)$.

Concentrations of chemical constituents in water are given either in milligrams per liter (mg/L) or micrograms per liter ( $\mu \mathrm{g} / \mathrm{L})$.

\title{
Acronyms
}

\author{
GIS Geographic Information System \\ IPCC Intergovernmental Panel on Climate Change \\ USGS U.S. Geological Survey
}


THIS PAGE INTENTIONALLY LEFT BLANK 


\title{
Preliminary Investigation of the Effects of Sea-Level Rise on Groundwater Levels in New Haven, Connecticut
}

\author{
By David M. Bjerklie, ${ }^{1}$ John R. Mullaney, ${ }^{1}$ Janet R. Stone, ${ }^{1}$ Brian J. Skinner, ${ }^{2}$ and Matthew A. Ramlow ${ }^{2}$
}

\section{Abstract}

Global sea level rose about 0.56 feet $(\mathrm{ft})$ (170 millimeters $(\mathrm{mm})$ ) during the 20th century. Since the 1960s, sea level has risen at Bridgeport, Connecticut, about $0.38 \mathrm{ft}(115 \mathrm{~mm})$, at a rate of $0.008 \mathrm{ft}(2.56 \mathrm{~mm} \pm 0.58 \mathrm{~mm})$ per year. With regional subsidence, and with predicted global climate change, sea level is expected to continue to rise along the northeast coast of the United States through the 21st century. Increasing sea levels will cause groundwater levels in coastal areas to rise in order to adjust to the new conditions. Some regional climate models predict wetter climate in the northeastern United States under some scenarios. Scenarios for the resulting higher groundwater levels have the potential to inundate underground infrastructure in lowlying coastal cities.

New Haven is a coastal city in Connecticut surrounded and bisected by tidally affected waters. Monitoring of water levels in wells in New Haven from August 2009 to July 2010 indicates the complex effects of urban influence on groundwater levels. The response of groundwater levels to recharge and season varied considerably from well to well. Groundwater temperatures varied seasonally, but were warmer than what was typical for Connecticut, and they seem to reflect the influence of the urban setting, including the effects of conduits for underground utilities. Specific conductance was elevated in many of the wells, indicating the influence of urban activities or seawater in Long Island Sound.

A preliminary steady-state model of groundwater flow for part of New Haven was constructed using MODFLOW to simulate current groundwater levels (2009-2010) and future groundwater levels based on scenarios with a rise of $3 \mathrm{ft}(0.91$ meters $(\mathrm{m})$ ) in sea level, which is predicted for the end of the 21st century. An additional simulation was run assuming a 3- $\mathrm{ft}$ rise in sea level combined with a 12-percent increase in groundwater recharge. The model was constructed from existing hydrogeologic information for the New Haven area and from new information on groundwater levels collected during October 2009-June 2010.

For the scenario with a 3-ft rise in sea level and no increase in recharge, simulated groundwater levels near the coast rose $3 \mathrm{ft}$; this increased water level tapered off toward a discharge area at the only nontidal stream in the study area. Simulated stream discharge increased at the nontidal stream because of the increased gradient. Although groundwater levels rose, the simulated difference between the groundwater levels in the aquifer and the increased sea level declined, indicating that the depth to the interface between freshwater and saltwater may possibly decline. Simulated water levels were affected by rise in sea level even in areas where the water table was at 17-24 ft (5.2-7.3 m) above current (2011) sea level. For the scenario with increased recharge, simulated groundwater levels were as much as an additional foot higher at some locations in the study area.

The results of this preliminary investigation indicate that groundwater levels in coastal areas can be expected to rise and may rise higher if groundwater recharge also increases. This finding has implications for the disposal of stormwater through infiltration, a low-impact development practice designed to improve water quality and reduce overland peak discharge. Other implications include increased risk of basement flooding and increased groundwater seepage into underground sewer pipes and utility corridors in some areas. These implications will present engineering challenges to New Haven and Yale University.

The preliminary model developed for this study can be the starting point for further simulation of future alternative scenarios for sea-level rise and recharge. Further simulations could identify those areas of New Haven where infrastructure may be at greatest risk from rising levels of groundwater.

${ }^{1}$ U.S. Geological Survey.

${ }^{2}$ Yale University. 
The simulations described in this report have limitations due to the preliminary scope of the work. Approaches to improve simulations include but are not limited to incorporating:

- The variable density of seawater into the model in order to understand the current and future location of the interface between freshwater and saltwater;

- Collection of additional data in order to better resolve temporal and spatial patterns in water levels in the aquifer;

- Improved estimates of recharge through direct and indirect measurements of freshwater discharge from the study area; and

- Transient simulations for greater understanding of the amount of time required for water levels and the position of the interface between freshwater and saltwater to adjust to changes in sea level and recharge.

\section{Introduction}

Global circulation models predict future rise in sea level and increasing precipitation in the northeastern United States, including in Connecticut (Gornitz and others, 2004). Such changes can raise groundwater levels thereby increasing the risk for flooding in basements and in other underground infrastructure such as pipes and tunnels. Gornitz and others (2004), Kirshen and others (2008), and Gornitz and Rosenzweig (2009) have evaluated the question of rise in sea level as an aspect of climate change in the northeastern United States; specifically the frequency, duration, and height of near-shore tidal inundation and storm surges and the potential effects on infrastructure such as transportation corridors, buildings, and utilities. The common conclusion from these studies is that significant risks are to be expected from rising sea levels and from the possibility of increasing frequency and intensities of coastal storms. The potential effects on subsurface infrastructure of these rising groundwater levels in response to rise in sea level and to changes in recharge, however, have not been studied to the same extent as the predicted changes in air temperature and storms. Rising groundwater levels could present long-term issues for water management that could be very costly to mitigate even though they are not catastrophic (Nicholls, 1995).

New Haven is a coastal city in Connecticut. Much of the land surface in the downtown New Haven area is less than 30 feet (ft) in altitude, and the city contains large areas of filled land that were originally part of New Haven Harbor. The aquifer underlying most of downtown New Haven comprises glacial stratified deposits overlying fine-grained glaciolacustrine deposits. A detailed description of the surficial geology is given in appendix 1.

Brown (1928) stated that in 1920, most of New Haven's 162,537 residents received water from public surface-water supplies; these are still the primary water source in 2012. During the early years of the 20th century, however, extensive withdrawals of groundwater were used for industrial purposes. Historically, the pumping allowed seawater to intrude into the aquifer to such an extent that wells in large areas of New Haven had high chloride levels (Mazzaferro, 1973) (fig. 1). Estimates of historical groundwater use in New Haven ranged from 3 to 5 million gallons per day (Mgal/d) (Brown, 1928). Pumping for industrial uses has ceased (R.H. Miller, City Engineer, New Haven, written commun., April 13, 2011) and groundwater levels in parts of New Haven appear to be higher than they were during the early part of the 20th century. Measurements from a U.S. Geological Survey (USGS) observation well (NHN235) (figs. 1 and 2), during 1940-75, show a general increase in water level of about $4 \mathrm{ft}$ $(1.2 \mathrm{~m})$ in an area of New Haven that was subject to most of the pumping (Brown, 1928, fig. 17).

Yale University occupies a large part of the city of New Haven, with over 300 buildings on 310 acres. The University's plan for modernizing the campus involves new building projects and a comprehensive program to renovate existing buildings. Yale is therefore concerned that they will have to take into account that the rising sea level and increased precipitation and concurrent rising groundwater levels may result in increased flooding of basements, and seepage into underground sewer pipes, utility corridors, and other subsurface infrastructure. A rise in sea level will increase salinity in the aquifer as seawater further intrudes and because of increased dewatering to lower groundwater levels. Rising salinity of groundwater in coastal areas is associated with corrosion of subsurface structures, such as those required for the conduit of water, sewer, steam, and electrical utilities.

The USGS, in collaboration with Yale University, conducted this preliminary study of groundwater levels in New Haven, during 2009-10, along with preliminary simulations of groundwater levels under current and potential future conditions of rise in sea level and increase in recharge. This study uses a model of groundwater flow to illustrate concepts associated with rising sea levels in southern New England and summarizes many of the limitations relating to complexities in the groundwater-flow system as well as some of the additional information necessary to continue research on this topic. 


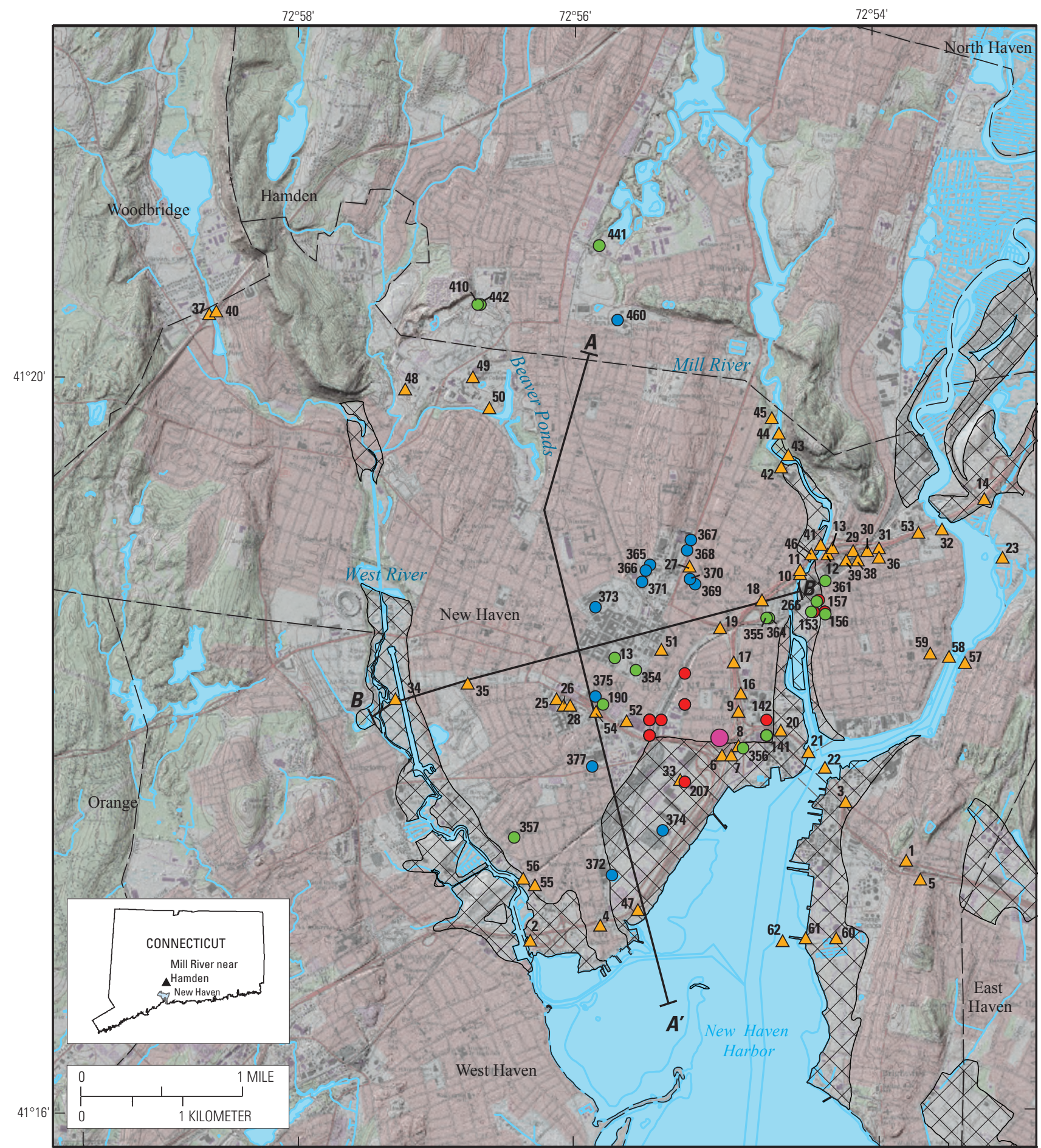

Base from U.S. Geological Survey, New Haven Quadrangle, 1:24,000

EXPLANATION

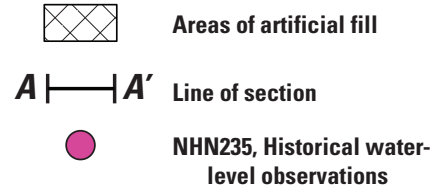

Wells with chloride concentrations greater than or equal to $\mathbf{2 5 0}$ milligrams per liter in 1938-1949 (Mazzaferro, 1973)

367

Wells where water-level measurements made from 2009-10 and New Haven or Hamden local identifier
Artificial fill areas from Stone and others (1992)

357

Wells with logs from Mazzaferro (1973), and New Haven or Hamden local identifie

${ }^{1} \triangle$ Test holes from Mazzaferro (1973), and New Haven local identifier

Figure 1. Study area, New Haven, Connecticut. 


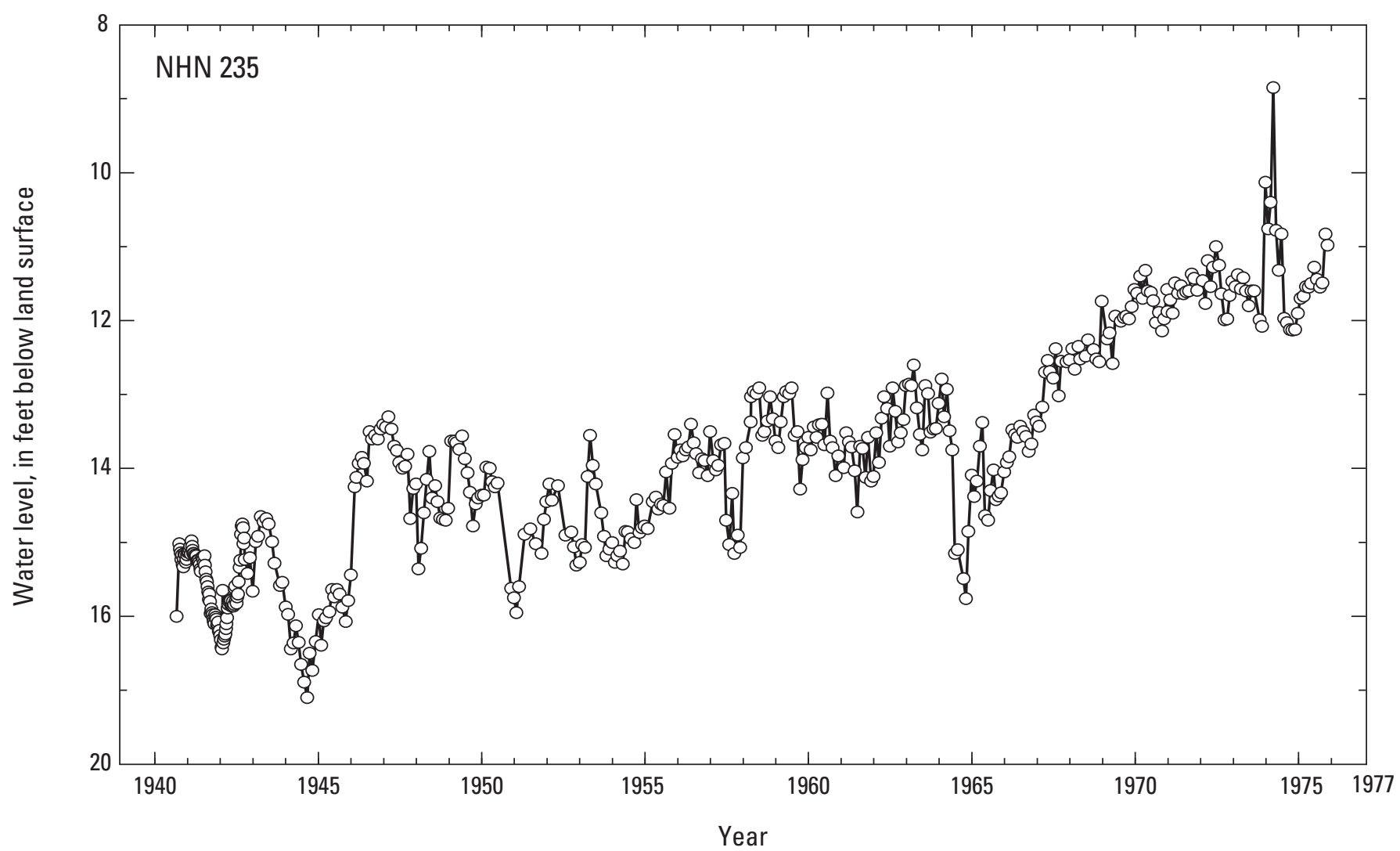

Figure 2. Water levels in observation well NHN235, New Haven, Connecticut, 1940-75. Location shown on figure 1.

\section{Purpose and Scope}

This report summarizes (1) the current information on projected rise in sea level in Long Island Sound; (2) new and existing information on the geology and groundwater levels in New Haven; (3) the use of a preliminary model of groundwater flow to test hypotheses on the effects of rise in sea level and of increasing recharge on groundwater levels in New Haven; and (4) the limitations of the model, describing some of the complexities involved in and information needed for developing a more detailed model of groundwater flow.

The study area of this report is confined to a portion of the City of New Haven that is bounded by New Haven Harbor (part of Long Island Sound) on the south, the West River on the west, and the Mill River on the east (fig. 1). The preliminary model developed for this study can be used (1) to evaluate alternative scenarios for rise in sea level and increase in recharge, particularly the potential for a greater rise in sea level by the end of the century; and (2) to identify those areas of New Haven where infrastructure may be at greatest risk from rising groundwater levels.

\section{Previous Investigations}

Few site-specific studies in Connecticut or in other areas of the United States have evaluated the explicit effects of the rise in sea level and changing recharge on groundwater levels. This issue is often not considered in coastal planning for rise in sea level. The more general assessments that are available include Barlow (2003) and Masterson and Garabedian (2007). Masterson and Garabedian (2007) used SEAWAT, a groundwater flow simulation code (Guo and others, 2002), to evaluate the nature of the freshwater/saltwater interface in the sand and gravel aquifer system on Cape Cod, Massachusetts. The study found that the distribution of freshwater and saltwater was similar to theoretical constraints (fig. 3), with the depth to the interface between freshwater and saltwater decreasing proportionally to an increase in the altitude of the water table above local sea level. 


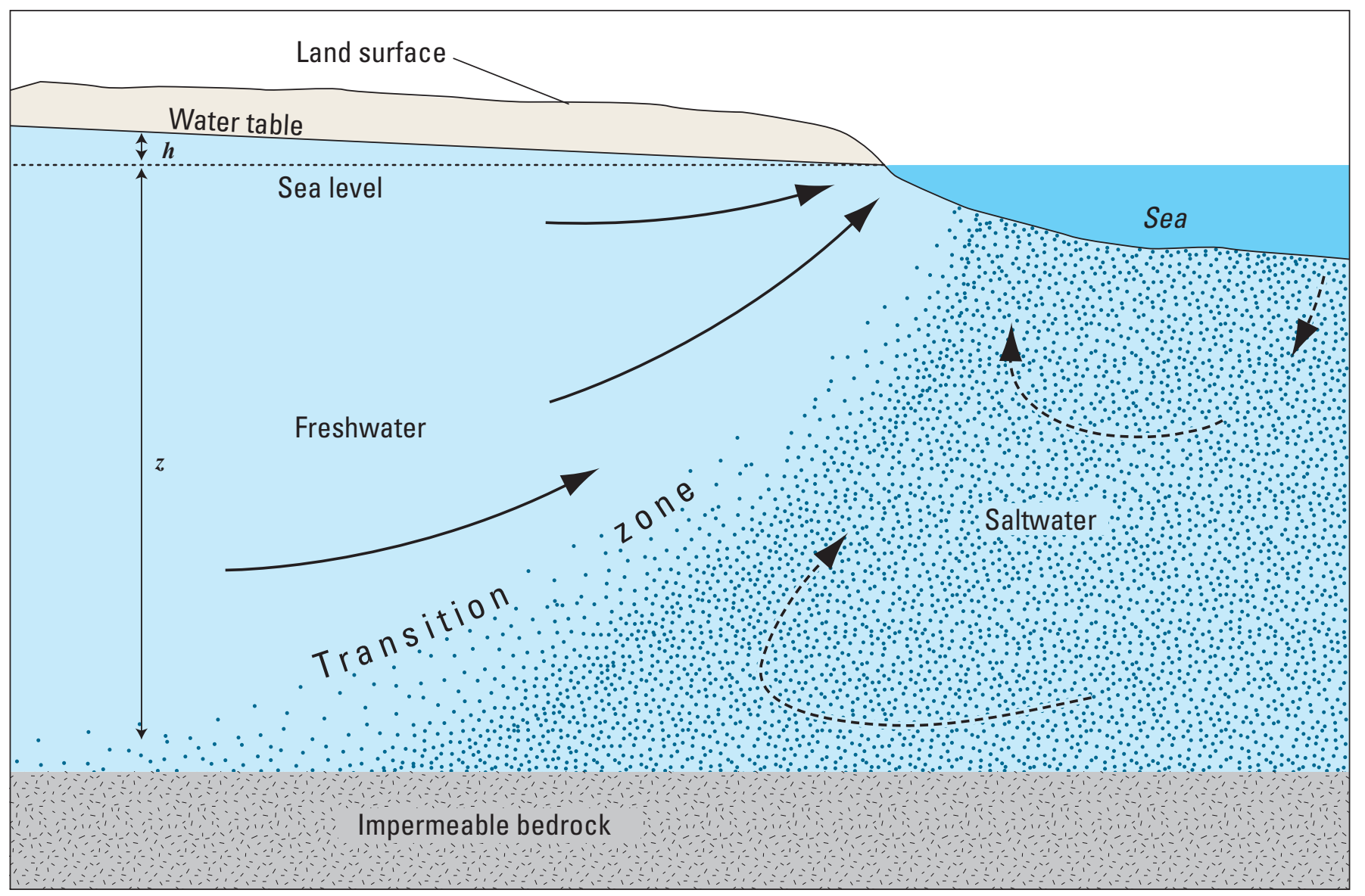

Not to scale

Modified from Cooper (1964)

Figure 3. Groundwater-flow patterns and interface between freshwater and saltwater in an idealized coastal aquifer. [h, altitude of water table above local sea level; $z$, depth to the interface between freshwater and saltwater below local sea level]

The distribution of saline water in an aquifer under steady-state conditions is primarily a function of the difference in density between seawater and freshwater. The water-table configuration and depth to the bottom of freshwater also are primarily a function of the drainage to surface water (Masterson, 2004; Masterson and Garabedian, 2007), the amount of pumping (Barlow 2003; Masterson 2004), and the amount of recharge to groundwater (Masterson, 2004; Werner and Simmons, 2009). The theoretical study by Werner and Simmons (2009) showed that in a groundwater system in which discharge to the sea is constant, rising sea level will not cause the saltwater wedge beneath the freshwater in the coastal aquifer to advance very far inland. This indicates that so long as recharge does not decrease and there are no additional withdrawals or diversion of groundwater from the aquifer, rising sea level will probably not increase the risk of the intrusion of saltwater inland. On the other hand, the same study by Werner and Simmons (2009) showed that, in a groundwater system in which inland groundwater levels remain constant as sea level rises, the saltwater wedge may advance a great distance inland. This latter case might occur if dewatering and drainage controls are put in place to counter the rise of groundwater level that can result from rising sea level.

Other recent studies include simulation of the effects of sea-level rise on groundwater levels and the position of the interface between freshwater and saltwater at Shelter Island, New York (Rozell and Wong, 2010). Oude Essink and others (2010) modeled the effects of sea-level rise in the Netherlands, Yechieli and others (2010) studied the effects of sea-level variations on the Mediterranean and Dead Sea coastal aquifers, and Watson and others (2010) analyzed the transient response of salt water intrusion to sea-level rise.

Previous studies of the hydrogeology of the New Haven area were done by Brown $(1925,1928)$ and Mazzaferro $(1973)$. The bedrock surface was most recently mapped by Haeni and Sanders (1974). Surficial geology was mapped by Flint (1965) and by Stone and others $(1992,2005)$. 


\section{Summary of Current Information on Future Rise in Sea Level in Long Island Sound}

The Intergovernmental Panel on Climate Change (IPCC) has estimated that sea level has risen globally during the 20th century by about $0.56 \mathrm{ft}(170 \mathrm{~mm}$ ) (note: all IPCC (2007) values are in metric units) (IPCC, 2007). The IPCC (2007) also reports that the rate of global rise in sea level has increased during the same period. The rate of rise from 1961 through 2003 was 0.0059 feet per year (ft/yr) (1.8 millimeters per year $(\mathrm{mm} / \mathrm{yr}))$, while the rate of rise from 1993 through 2003 was $0.010 \mathrm{ft} / \mathrm{yr}$ $(3.1 \mathrm{~mm} / \mathrm{yr})($ IPCC 2007$)$. One of the anticipated effects of warmer global temperatures is continued acceleration in the rate of rise in sea level due to thermal expansion as ocean temperatures increase in response to rising mean air temperatures. In addition, melting glaciers, both alpine and continental (on Greenland and Antarctica), will contribute to rise in sea level. Estimates of the amount of rise in global temperature that may take place during the 21 st century and on the extent to which melting glacier ice may play a role in that rise vary widely.

Although thermal expansion of ocean waters is relatively well understood and can be predicted with reasonable confidence, the dynamics of ice sheets are poorly understood. The IPCC (2007) assigned the 95-percent confidence interval to the estimates of global rise in sea level. The interval was estimated to be $0.58-1.9 \mathrm{ft}(180-590 \mathrm{~mm})$ by $2090-2099$, or $0.005-0.032 \mathrm{ft}(1.5-$ $9.7 \mathrm{~mm}$ ) per year. Several individual studies, however, have estimated global rise in sea level to be an order of magnitude larger than the IPCC estimates. Overpeck and others (2006), for example, predict global rise in sea level by the year 2100 to be on the order of meters rather than in centimeters even though the actual value is highly uncertain because of similar uncertainty about how ice sheets will respond to global warming. In addition, recent research has indicated that groundwater withdrawals globally may be contributing to sea-level rise by removing water from underground storage and reintroducing water into the atmosphere by evapotranspiration (Wada and others, 2010).

Although the IPCC (2007) considers the collapse of the West Antarctic Ice Sheet or the rapid loss of the Greenland Ice Sheet to be unlikely during the 21 st century, the panel states that "the occurrence of such changes becomes increasingly more likely as the perturbation of the climate system progresses." The total amount of ice in the Greenland Ice Sheet represents about $23 \mathrm{ft}(7 \mathrm{~m})$ of rise in sea level, while the total amount of ice in the West Antarctic ice sheet represents about $16.4 \mathrm{ft}(5 \mathrm{~m})$ of rise in sea level (IPCC, 2007, chapter 10).

Other models predict a rise in sea level in Connecticut of $0.43-0.69 \mathrm{ft}(130-211 \mathrm{~mm})$ by $2020,0.68-1.39 \mathrm{ft}(206-424 \mathrm{~mm})$ by 2050 , and $0.93-2.92 \mathrm{ft}(284-897 \mathrm{~mm}$ ) by 2080 (Gornitz and others, 2004). During the previous 1,000 years, sea level has been rising along the East Coast of the United States at rates of 0.04-0.06 ft (13-18 mm) per decade. The basis for this estimate is stratigraphic evidence from coastal salt marshes (Nydick and others, 1995). Approximately $0.025 \mathrm{ft} / \mathrm{yr}$ of that estimate can be attributed to regional subsidence as the Earth's crust still slowly re-adjusts to the melting of the ice sheets after the last ice age (Gornitz and Rosenzweig, 2009; Gornitz and others, 2002). Since about 1860, however, as global temperatures have increased, regional sea level has been rising more rapidly than during the previous 1,000 years (Varekamp and others, 1992; Nydick and others, 1995; Van de Plassche and others, 1998; Donnelly and others, 2004; Holgate and Woodworth, 2004; and Gehrels and others, 2005).

During 1938-2006, tide gages at New London, Conn., show an average rate of rise in sea level of $0.007 \mathrm{ft} / \mathrm{yr}(2.25 \mathrm{~mm} / \mathrm{yr} \pm$ $0.25 \mathrm{~mm}$ ) (National Oceanic and Atmospheric Administration, 2011); during 1964-2006, tide gages at Bridgeport, Conn., show an average rate of rise in sea level of $0.008 \mathrm{ft} / \mathrm{yr}(2.56 \mathrm{~mm} / \mathrm{yr} \pm 0.58 \mathrm{~mm})$ (fig. 4). Because of the rate of land subsidence, these data exceed the eustatic rate of rise in sea level of 0.002 to $0.005 \mathrm{ft} / \mathrm{yr}(0.5-1.5 \mathrm{~mm} / \mathrm{yr})$ during this period.

\section{Conceptualization of the Hydrologic System in New Haven}

Groundwater flow beneath the New Haven area occurs primarily in the glacial stratified deposits that dominate much of the study area. These glacial meltwater deposits are deltaic (appendix 1), with coarse-grained topset beds overlying foreset beds and bottomset beds. The bottomset beds are fine-grained lacustrine deposits, with limited groundwater flow especially at depth, due to the low permeability of the sediments. Infiltration of precipitation to the water table accounts for the majority of recharge to this aquifer. Urbanization since the early 18 th century has probably changed the patterns of recharge because impervious surfaces re-route water to storm drains, and water and sanitary sewer lines commonly leak. Water that has been recharged locally discharges toward the Mill River, the West River, to New Haven Harbor, or to the streams draining from Beaver Ponds Park. The Mill River and West River are tidally influenced, although the magnitude of tidal fluctuations is limited by tide gates. In the urban environment, groundwater may leave the aquifer through preferred pathways such as storm drains, or through disturbed areas where utility lines are deeper than the water table.

Groundwater velocity is about $0.1-0.5$ feet per day (ft/d), based on (1) the approximate gradient of 0.001 , (2) the range of values expected for the horizontal hydraulic conductivity of the generally coarse-grained topset and foreset beds (40-100 ft/d), and (3) an assumed porosity of $0.2-0.3$. Residence time in the study area, therefore, could be as great as 75 to 380 years (neglecting any significant vertical flow component) for the longest flowpaths (from the northern part of the study area, to 


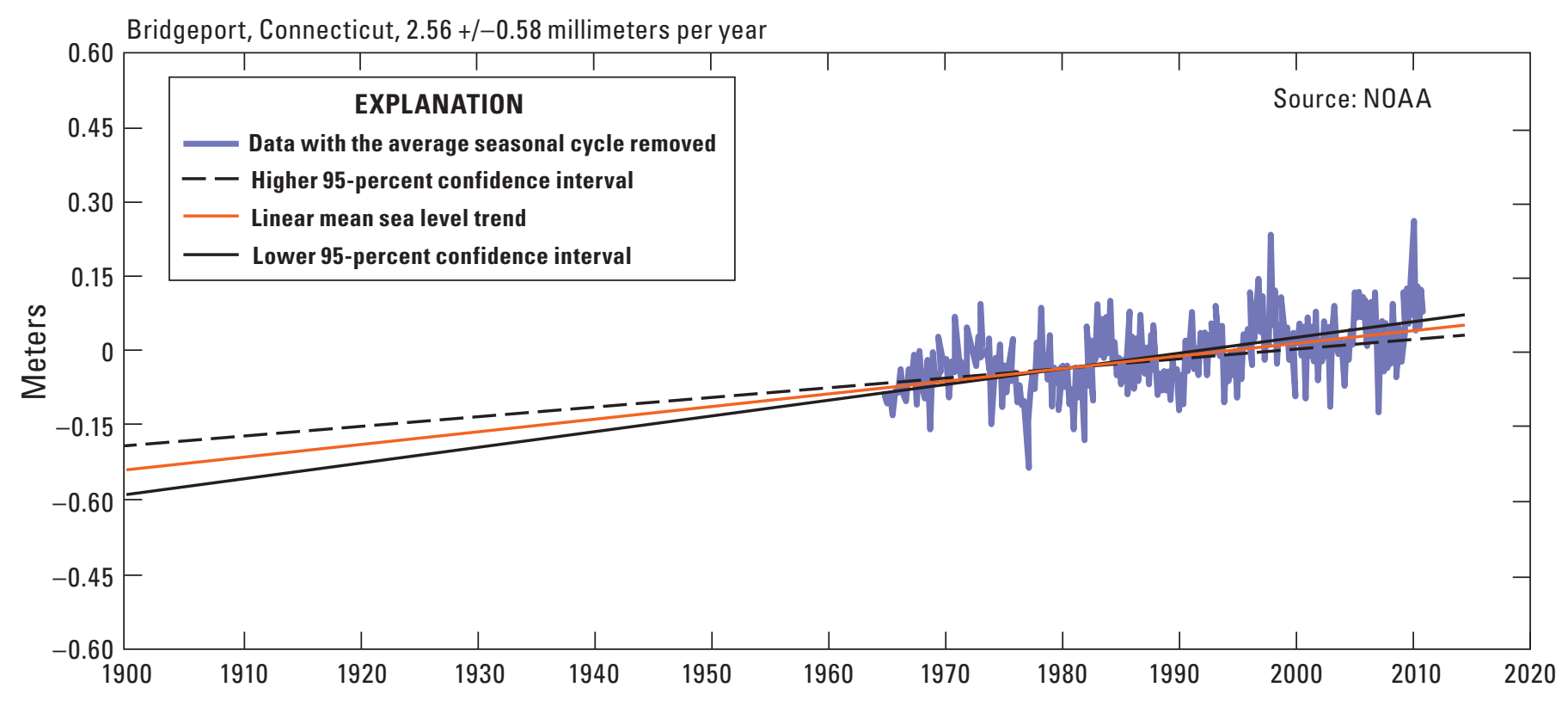

Figure 4. Change in sea level at Bridgeport, Connecticut, 1964-2010, reproduced from http://tidesandcurrents.noaa.gov/sltrends/ sltrends_station.shtml?stnid=8467150.

New Haven Harbor, fig. 1, A-A', from bend in the section to New Haven Harbor), and as great as 35 to 200 years for flowpaths from the groundwater divide to either the Mill River or the West River (fig. 1, from junction of sections A-A' and B-B' east to Mill River, or West to the West River). The minimum travel time from recharge to discharge would be less than one year in areas near rivers or New Haven Harbor. There are currently no major groundwater withdrawals (R.H. Miller, City Engineer, New Haven, written commun., April 13, 2011), but large volumes of water were pumped from this aquifer during the early 20th century (Brown, 1928).

Groundwater residence time in the underlying fined-grained bottomset beds can be expected to be an order of magnitude greater than that for the topset and foreset beds. Travel time for the longest flowpaths in this layer (assuming that flow stays in this layer, without much vertical flow) could be as much as 600 to 13,000 years based on a horizontal hydraulic conductivity ranging from 1 to $12 \mathrm{ft} / \mathrm{d}$, porosity of 0.2 to 0.3 , and a gradient of 0.001 (velocity of 0.003 to $0.06 \mathrm{ft} / \mathrm{d}$ ). Information on the current position of the freshwater/saltwater interface is limited. Brown (1925) describes artesian conditions in New Haven Harbor: mud in the harbor acts as an aquitard, and fresh groundwater exists under parts of the harbor. Brown (1925) notes that fresh groundwater could be withdrawn from wells on areas of filled land that were as much as 1,000 ft from the original shoreline, and he also describes the intrusion of seawater into the aquifer in areas near the shoreline, due to excessive pumping in the early 20 th century. Tidal influence on the groundwater system probably influences the transition from fresh water to saltwater because of mixing, creating a brackish transitional zone.

\section{Methods}

Geologic material, stratigraphy, water quality, and groundwater-level data were compiled from existing sources for the New Haven area. To supplement the existing data, the study collected measurements of groundwater levels, temperature, and specific conductance at several existing shallow wells in the New Haven area during the one-year period August 2009 to September 2010. This dataset was used to develop a preliminary finite-difference model of groundwater flow for the New Haven area to test hypotheses regarding the effects of rise in sea level on groundwater levels. 


\section{Review of Existing Groundwater Data}

Groundwater data in the study area were compiled from existing USGS records and from additional data collected by Haley and Aldrich, Inc., at the request of Yale University. Most of the data compiled from USGS records had been reported in Mazzaferro (1973). Additional chloride data collected during 1938-49, a period in which significant industrial withdrawals of groundwater occurred in New Haven, were also reported in Mazzaferro (1973); these data were used to identify wells with historically elevated chloride levels which indicate areas that are potentially subject to saltwater intrusion. (Locations of wells are shown in fig. 1) For the present study, Haley and Aldrich, Inc. and the USGS located and identified existing wells in a field survey of the New Haven area. Based on the wells identified from the survey, the study selected 13 to measure water levels, specific conductance, and temperature.

Data on geology and groundwater flow conditions from test holes and borings (fig. 1) documented in previous USGS studies were used to create a preliminary model of groundwater flow and in understanding textural changes in the surficial deposits underlying the study area. Locations for all these test holes and borings were entered into a Geographic Information System (GIS) database.

\section{Water-Level, Temperature, and Specific-Conductance Monitoring}

Water levels, temperature, and specific-conductance of groundwater in the 13 wells were measured by USGS with assistance from Yale University. These data were compiled and tabulated along with the total well depth, and land surface altitude of each well (table 1). The field measurements of temperature and specific conductance are treated as relative and qualitative because of field conditions described below. Data for the wells include boring logs and well-completion diagrams, and in some cases limited data on water level and water quality. The borings and the wells are completed to depths ranging from 25 to $50 \mathrm{ft}$ below land surface with screened intervals ranging from 5 to $34 \mathrm{ft}$ below land surface. The wells were completed in generally fine to coarse sand (table 1). The wells were tested to determine adequate hydraulic connection to the aquifer by introducing a water-level displacement into the well and observing the response.

Manual measurements of water levels, temperature and specific conductance were made using a down-hole probe approximately monthly in all 13 wells. Measurements were made near the water surface in the well. The down-hole instrument was checked against standards in the lab several times during the course of the field program. Measurements of this type are considered qualitative because of potential differences among wells in the exchange of water in the well casing with the water from aquifer.

Water levels were measured continuously in six selected wells using submersible pressure transducers. Two wells (NHN369 and NHN370) were removed from service when ongoing construction work required their demolition; the monitoring equipment was moved to wells HM460 and NHN367 (table 1). Continuous temperature monitoring was done in eight of the monitoring wells. The instruments that recorded water-level and temperature fluctuation were installed near the top of the well screen. These data were checked against the field measurements of water levels and temperature made during each field visit.

\section{Modeling Groundwater Flow}

To test hypotheses regarding the effects of the rise in sea level on groundwater levels, the study created a preliminary model of groundwater flow using MODFLOW-2000 (Harbaugh and others, 2000). Details of the preliminary model, its development, and its assumptions and limitations are presented in appendix 2.

The preliminary model simulates steady-state long-term average conditions. The simulated heads in the model were compared with average measurements of water levels made at selected wells from October 2009 through June 2010 as a means to check the validity of the simulations. The model was then used to simulate two hypothetical scenarios of long-term increases in sea level and in recharge. The first of these scenarios assumed a rise in sea level of $3 \mathrm{ft}$ during the 100 years from 2000 to 2100. This value is consistent with the upper limit of predictions for Connecticut (Gornitz and others, 2004). The second scenario assumed a 3 - $\mathrm{ft}$ rise in sea level and a 12-percent increase in recharge, a value obtained by using downscaled Global Climate Model (GCM) data in a Precipitation Runoff Modeling System (PRMS) model of the drainage to Long Island Sound (Bjerklie and others, 2011). The PRMS model simulated groundwater recharge for two periods, 2001-2012 and 2088-2099, using temperature and precipitation data downscaled from the Bergen Climate Model version BCC-BCM2.0 GCM SRESa2 emission scenario (minimal changes to current rates of global $\mathrm{CO}_{2}$ emissions) developed at the Bjerknes Centre for Climate Research in Norway (IPCC, 2007). 


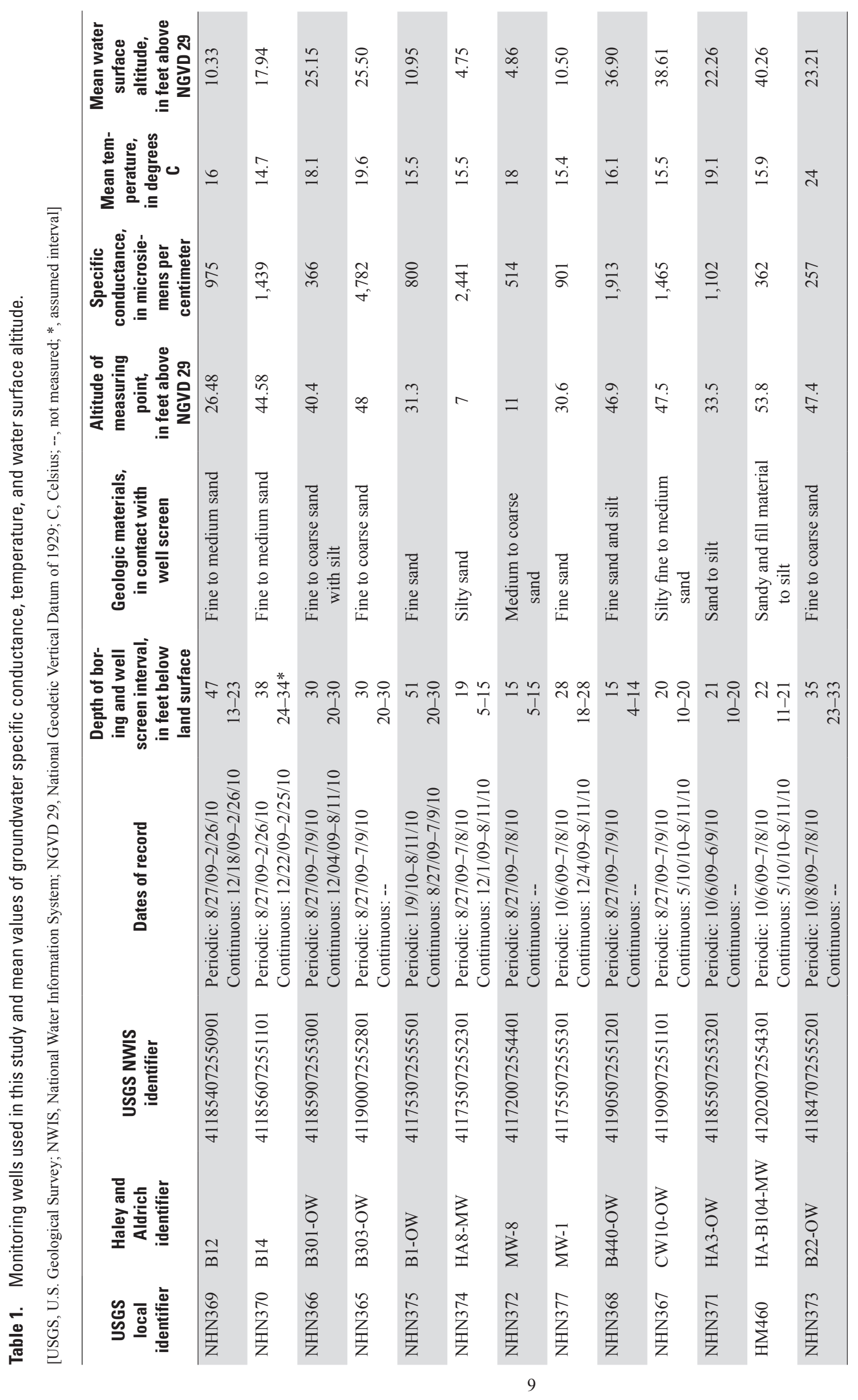




\section{Groundwater Monitoring Results}

During December 2009 through August 2010, groundwater observations indicate variable water level (fig. 5A) and temperature (fig. 5B). The water-level changes indicate a variable response of the water table to rainfall events, little or no tidal influence, and seasonal fluctuation similar to that observed for streamflow in the Mill River (streamgaging station number 01196620, location shown in fig. 1) (figs. 6A-G). The fluctuation in streamflow provides an indication of the magnitude of storm events and groundwater recharge in the New Haven area. All of the wells showed a seasonal pattern of change in water level that correlated with change in streamflow, suggesting a response to change in seasonal recharge. Well NHN374 showed more variable and rapid change in water level suggesting a more rapid response to recharge events. This well has the shallowest depth to the water table and also is the closest to the shore. Well NHN375 is screened beneath a paved area and so was isolated from direct recharge in the area, and shows the least short-term variability in water level, yet it still shows a seasonal response. All of the wells showed a general decline in water level through the summer months, except wells NHN369 and NHN370 which were destroyed in March due to construction.

The range of changes in groundwater levels in all 13 wells that were monitored monthly, which includes those with continuous recorders, varied depending on location. (Fig. 6 shows just the wells with continuous recorders). Six wells exhibited fluctuation of more than a foot (NHN365, NHN366, NHN367, NHN368, NHN374, and NHN375). Others showed a much smaller range in water levels (NHN369, NHN370, and NHN377). Water level in well NHN375 showed a change of more than $2 \mathrm{ft}$. The effect of groundwater dewatering associated with construction is evident from the water-level observations in well NHN373. This well is located directly across the street from a building construction site where dewatering was occurring from the beginning of the observation period until spring 2010. Groundwater levels in this well dropped to below the well screen during dewatering, rising over $7 \mathrm{ft}$ after dewatering had stopped.

Groundwater temperatures declined in winter 2009 and spring 2010 in response to lowering air temperature and the introduction of melting snow, followed by an increase in temperature in late spring in response to rising air temperature and rising temperature of precipitation and of recharge (figs. 7A-H). Groundwater temperature generally increased as groundwater levels declined, however the range of temperature change varied from well to well. The range in temperature change may be associated with well depth, as the shallowest well (NHN374) showed the largest temperature range and the deepest well (NHN375) showed the smallest temperature range. Well NHN374 showed significant temperature stratification in the well casing during manual measurements, a large change in temperature over time, and an earlier rise in temperature during the spring, indicating that it is highly influenced by external factors, possibly proximity to the harbor and (or) shallow depth of the well. Additionally, the higher temperatures in wells NHN366 and NHN374 indicate the possibility of heat input that is independent of natural recharge beneath the Yale campus. The mean values of field measurements of water level and of temperature are in table 1.

Grady (1993) reported that groundwater temperatures in stratified-drift deposits in forested areas had a median temperature of $12^{\circ} \mathrm{C}$, and commercial and industrial areas had a median temperature of $14^{\circ} \mathrm{C}$. Groundwater temperatures along the Connecticut coast may be slightly higher due to maritime influence. Groundwater temperatures measured during this study (table 1) would correspond to the commercial industrial areas noted by Grady (1993) and are generally higher than those typically reported for Connecticut. However, the short measurement period limits the conclusions that can be drawn from the data relative to longer-term mean values. The higher groundwater temperatures measured during this study suggest the influence of warmer recharge, for example, warmer water infiltrating from pavement runoff, leakage from water, storm or sanitary sewer utility conduits, or influence from other warm underground infrastructure. Graphs $7 \mathrm{~A}-\mathrm{H}$ show groundwater and temperature fluctuations in continuously monitored wells in New Haven for the period December 2009 to August 2010.

Specific conductance in the wells was elevated relative to typical measurements for Connecticut (Grady, 1993). Elevated specific conductance in the New Haven area probably represents urban influence from road salt and other solutes in stormwater infiltration, and similar data in areas near the shore could also represent urban influences and the mixing with intruded seawater. To confirm this latter possibility, future analysis could include measurement of the chloride/bromide ratio in water from some wells in order to identify the influence of seawater relative to other sources of high specific conductance (such as urban runoff). High chloride levels in some neighborhoods of New Haven have previously been associated with saltwater intrusion due to extensive pumping from the surficial aquifer (Mazzaferro, 1973). 

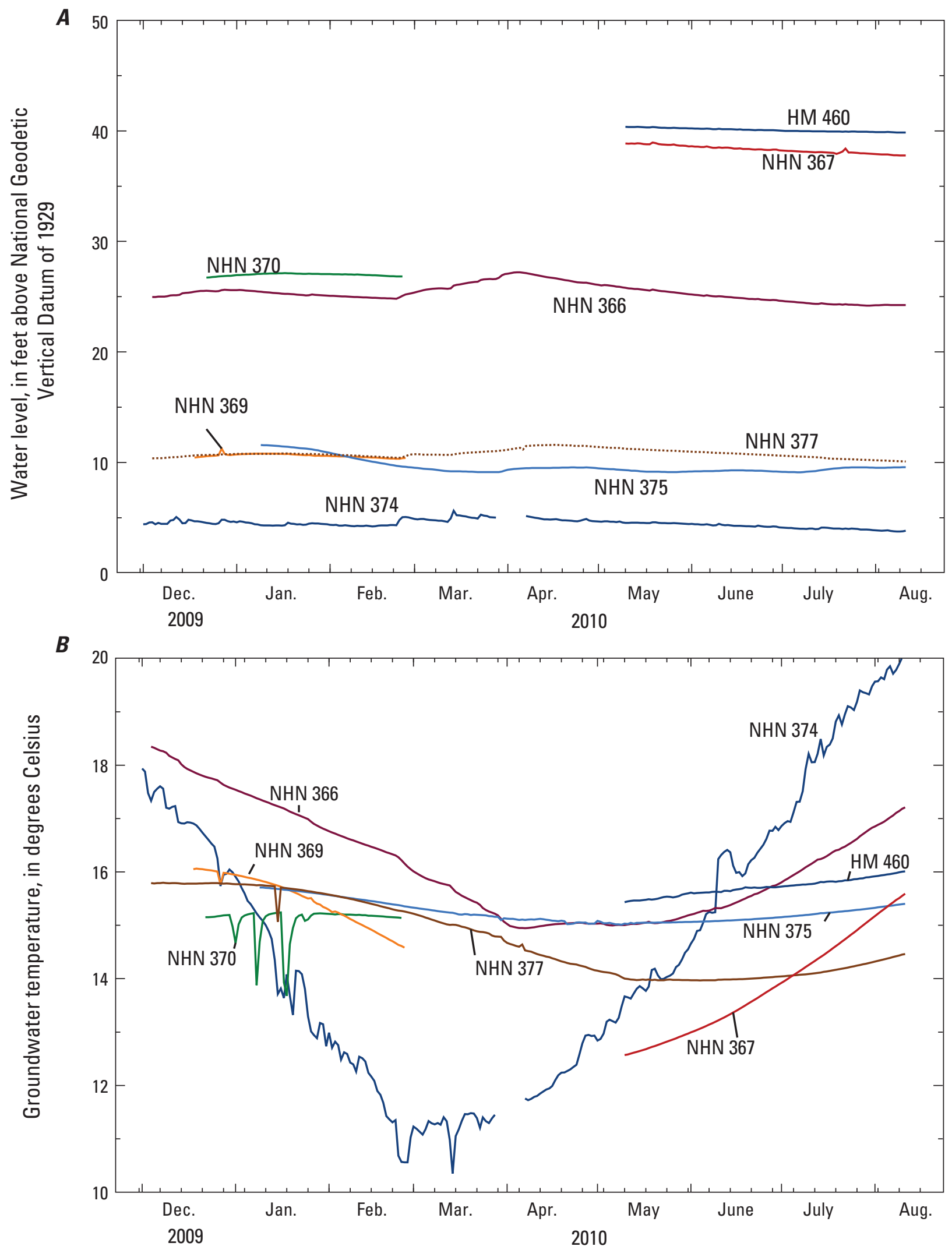

Figure 5. Groundwater-level fluctuation $A$, and groundwater temperature fluctuation $B$, for the period December 2009 to August 2010 in the continuous monitoring wells, New Haven, Connecticut. 


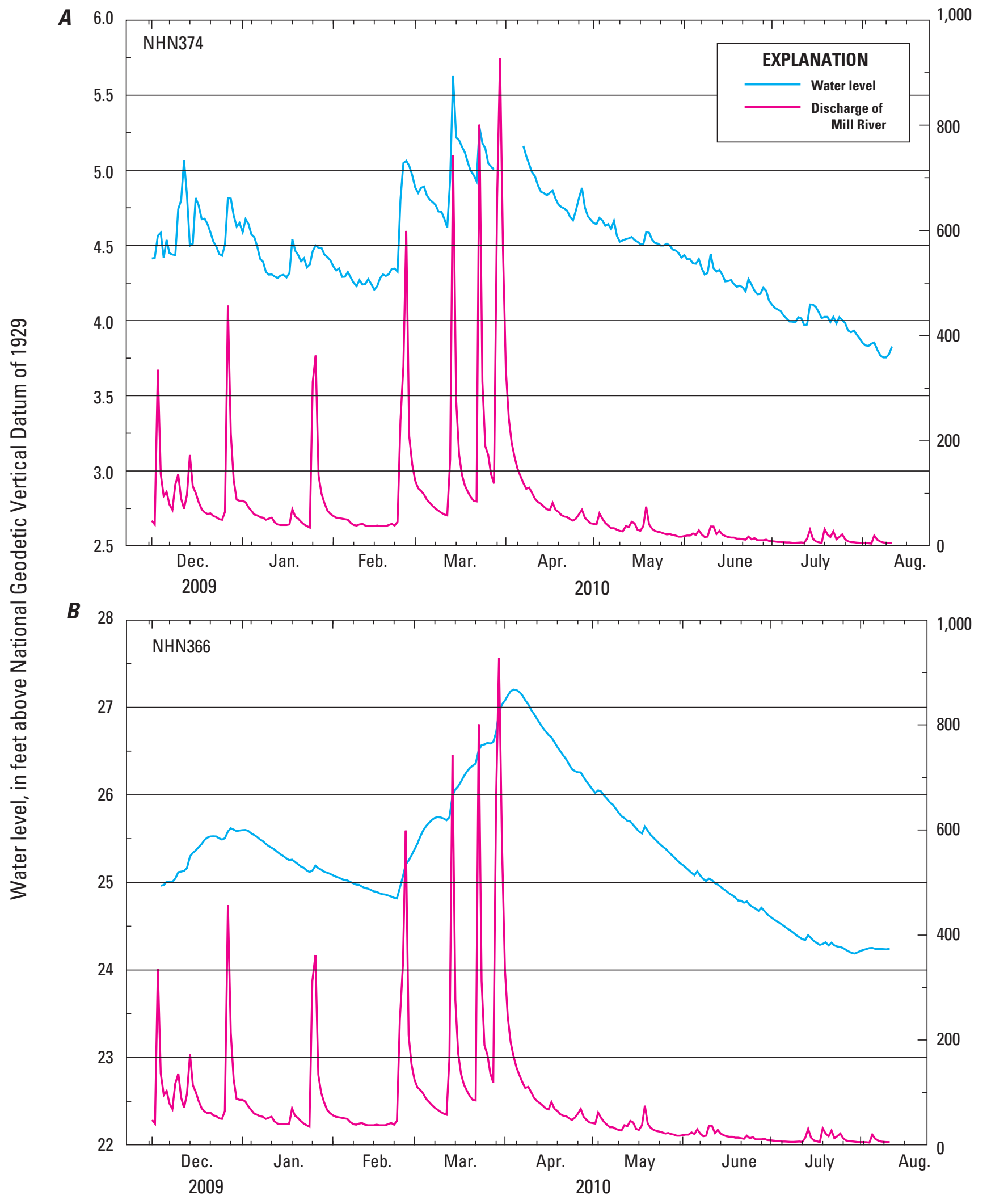

Figure 6. Groundwater-level fluctuation in relation to streamflow in the Mill River for the eight $(A-H)$ continuously monitored wells in New Haven, Connecticut, for the period December 2009 to August 2010. 


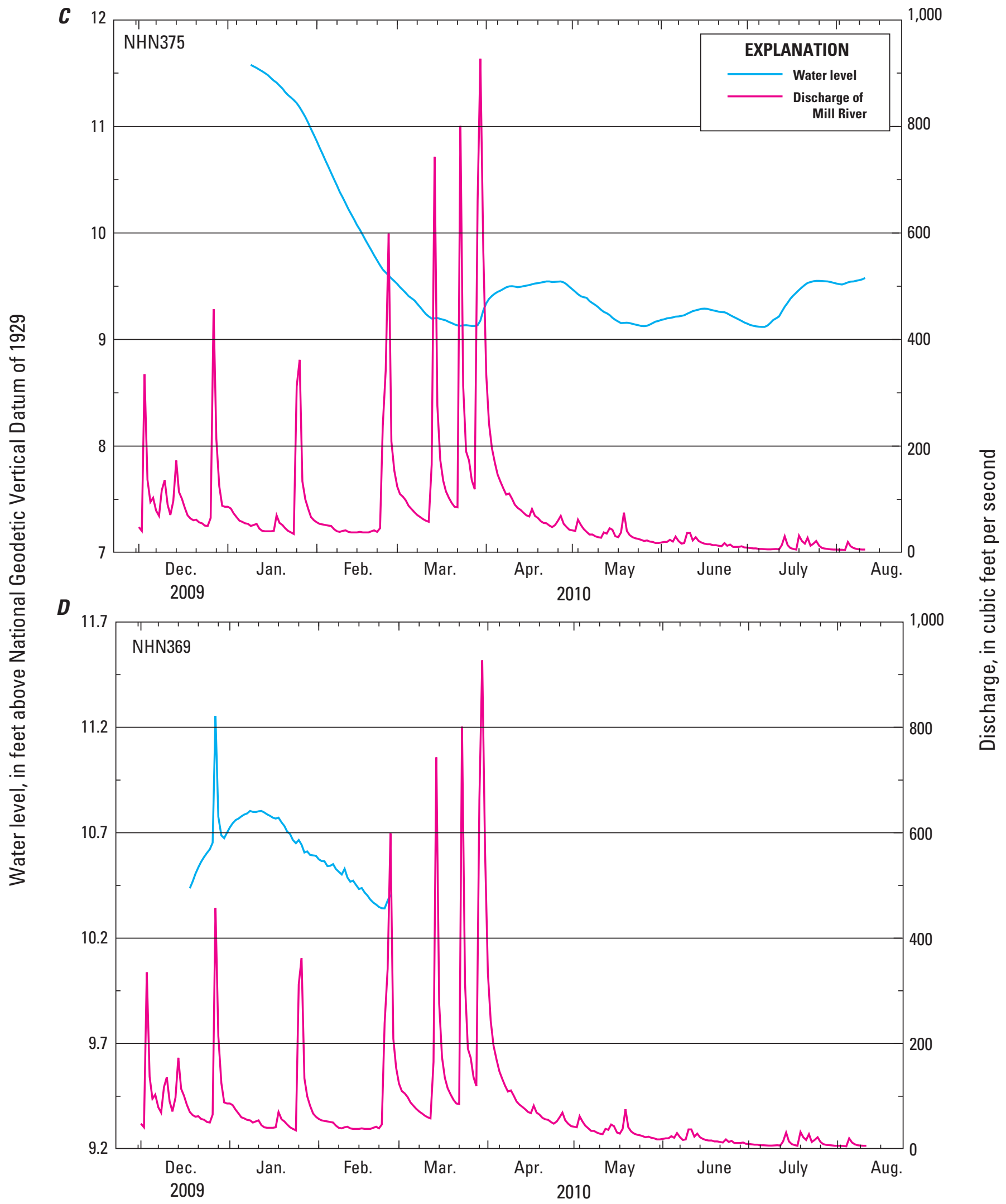

Figure 6. Groundwater-level fluctuation in relation to streamflow in the Mill River for the eight $(A-H)$ continuously monitored wells in New Haven, Connecticut, for the period December 2009 to August 2010.-Continued 


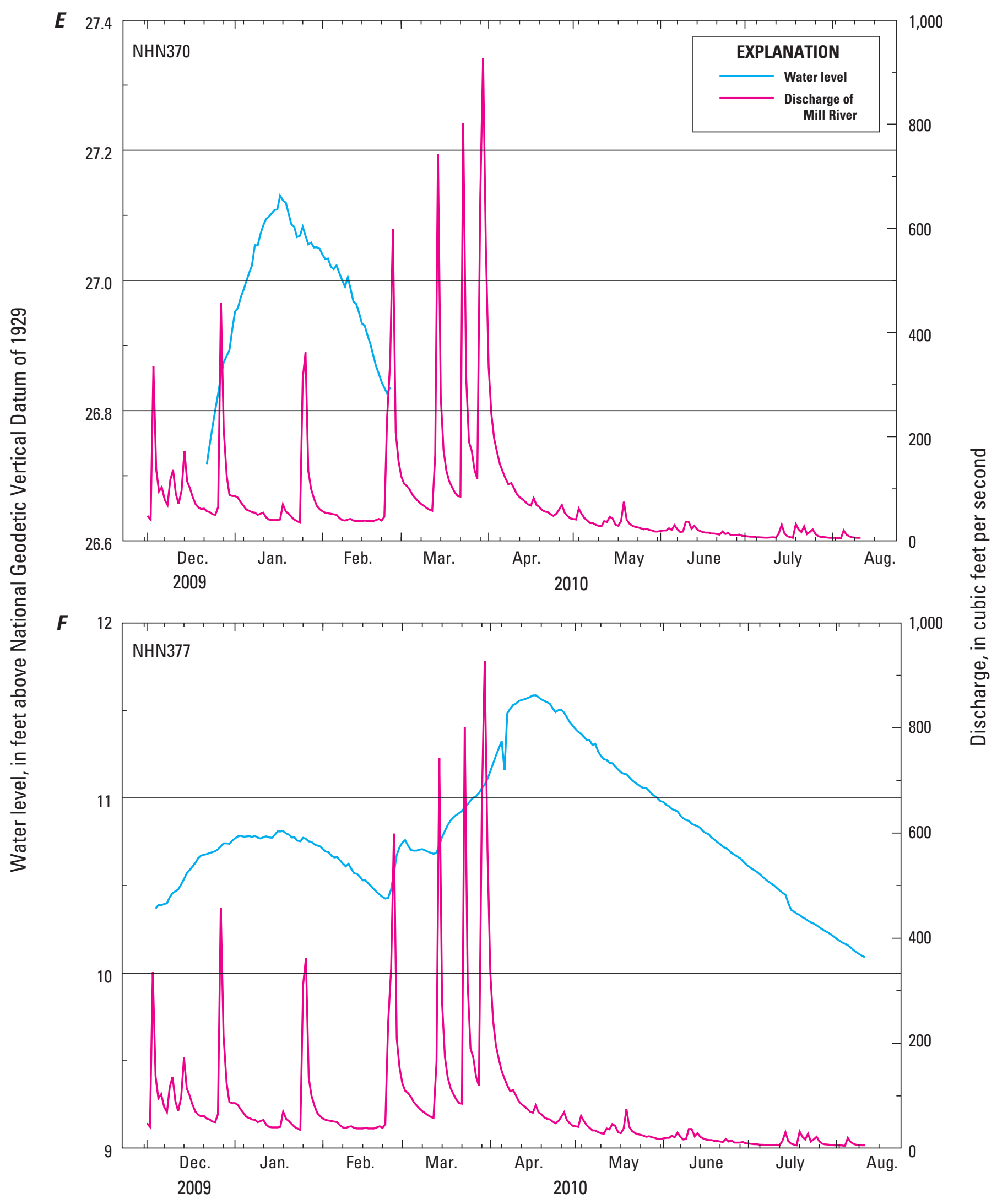

Figure 6. Groundwater-level fluctuation in relation to streamflow in the Mill River for the eight $(A-H)$ continuously monitored wells in New Haven, Connecticut, for the period December 2009 to August 2010.-Continued 


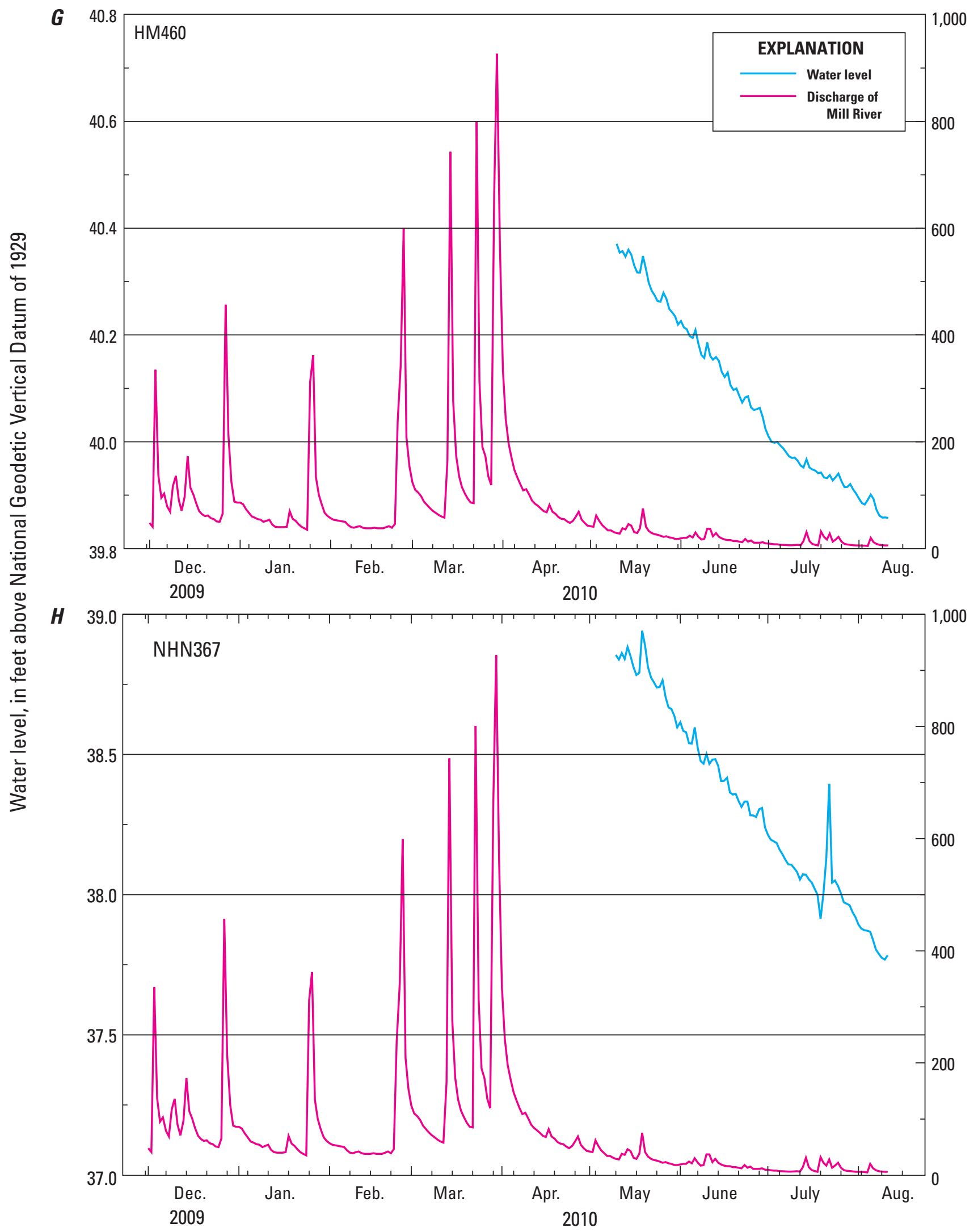

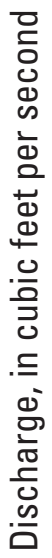

Figure 6. Groundwater-level fluctuation in relation to streamflow in the Mill River for the eight $(A-H)$ continuously monitored wells in New Haven, Connecticut, for the period December 2009 to August 2010. - Continued 


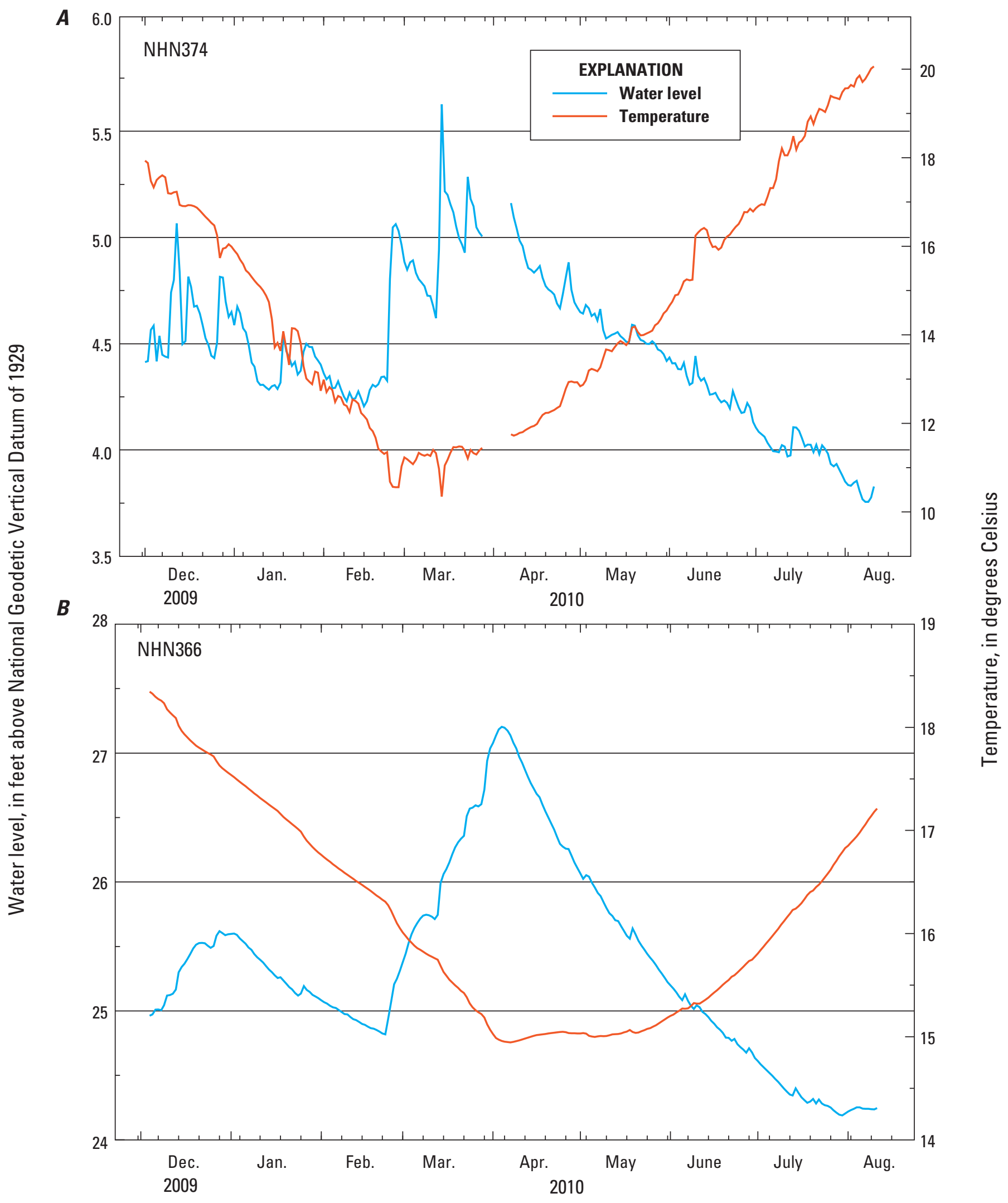

Figure 7. $(A-H)$ Groundwater and temperature fluctuations in continuously monitored wells, New Haven, Connecticut, for the period December 2009 to August 2010. 


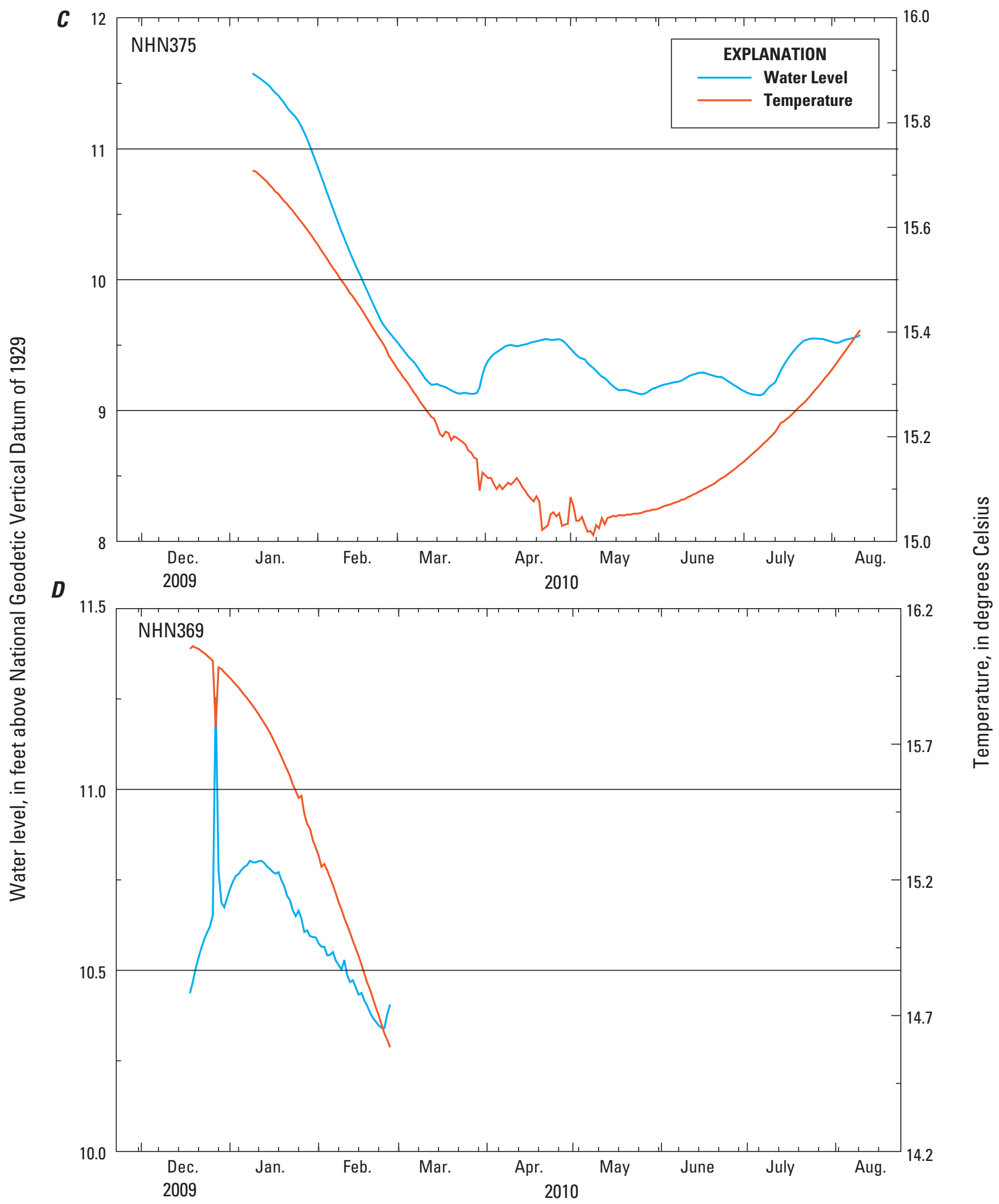

Figure 7. $(A-H)$ Groundwater and temperature fluctuations in continuously monitored wells, New Haven, Connecticut, for the period December 2009 to August 2010.-Continued 


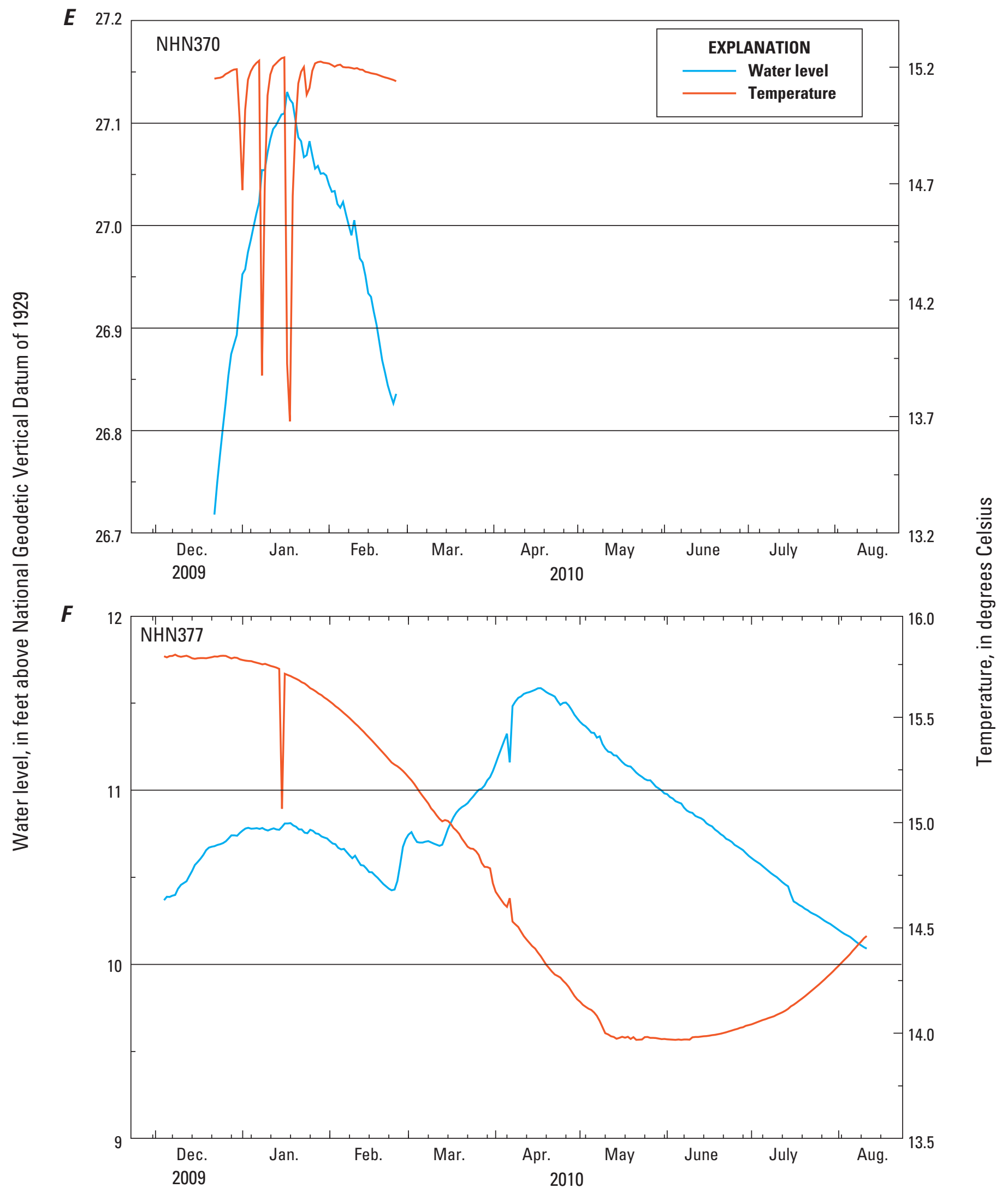

Figure 7. $(A-H)$ Groundwater and temperature fluctuations in continuously monitored wells, New Haven, Connecticut, for the period December 2009 to August 2010._- Continued 


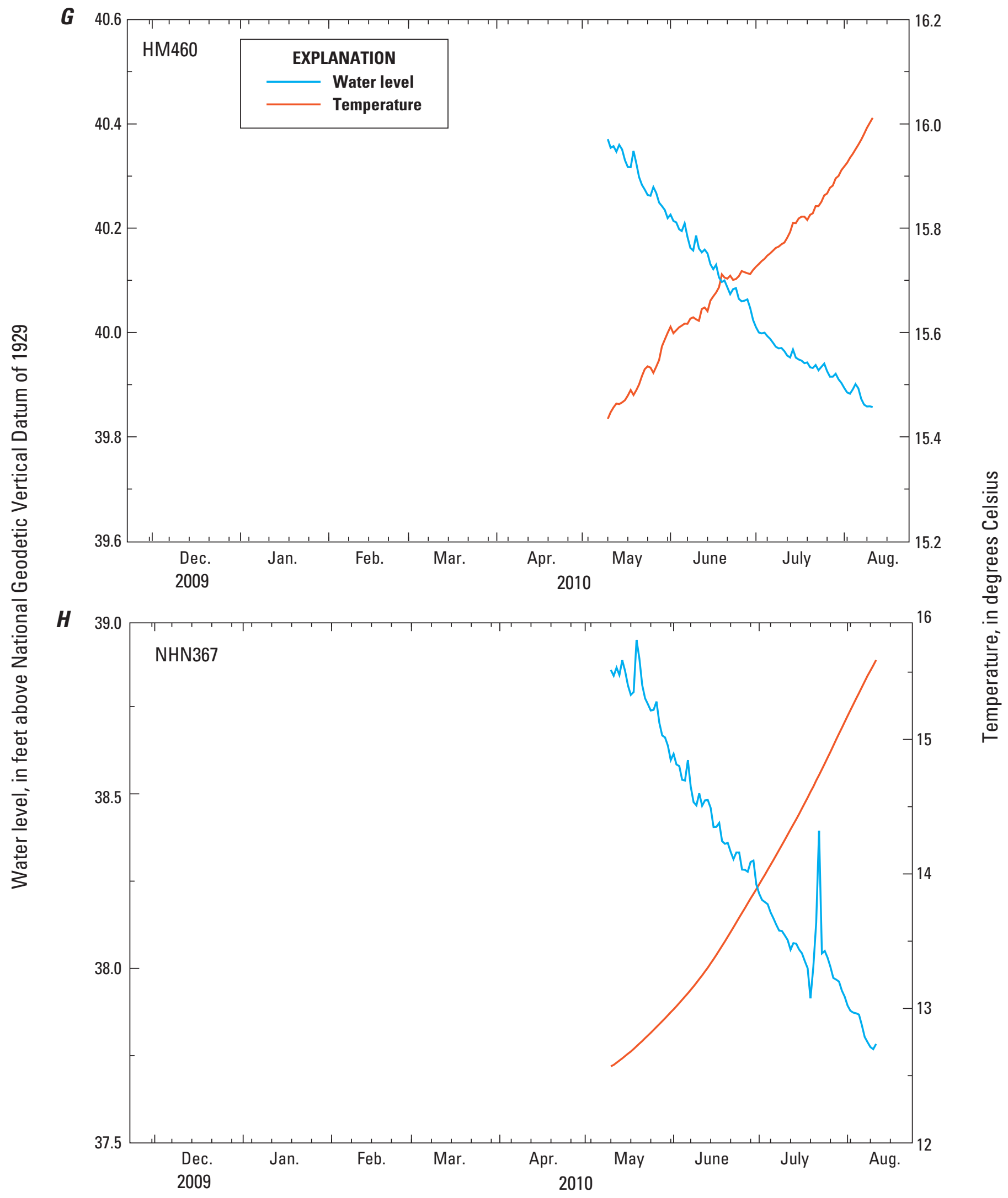

Figure 7. $(A-H)$ Groundwater and temperature fluctuations in continuously monitored wells, New Haven, Connecticut, for the period December 2009 to August 2010.-Continued 


\section{Simulation of Changes in Groundwater Levels}

A preliminary model of groundwater flow was developed using MODFLOW-2000 (Harbaugh and others, 2000) in order to test hypotheses regarding the effects of rise in sea level and of increased recharge on groundwater levels. The MODFLOW-2000 model is described in detail in appendix 2 . The preliminary model was based on the conceptual model of the local geology and groundwater flow and included estimates of hydraulic conductivity and recharge from previous studies. New Haven Harbor and the tidal reaches of the West River and the Mill River were simulated as constant-head boundaries; impervious cover, which averaged 37 percent for all active cells in the model, was assumed to limit recharge.

The simulated heads of the preliminary steady-state MODFLOW model (appendix 2) were compared with 11 mean water levels measured during this study, to check the validity of the simulation. The model was adjusted in order to simulate water-level response (1) to simulated rise in sea level with no increase in recharge and (2) to simulated rise in sea level with increase in recharge. In both simulations, sea level was adjusted upward $3 \mathrm{ft}$ by raising the altitude of the constant-head boundaries representing New Haven Harbor and by adjusting the altitude of simulated tidal portions of the West River and the Mill River. Although the West River and the Mill River have tide gates that limit the tidal range, the study assumed that the average altitude of these tidal rivers was at current sea level. Tidal fluctuations on these rivers were verified through field observations.

In the first simulation, sea level was adjusted upward by $3 \mathrm{ft}$. In the second simulation, sea level was adjusted upward by $3 \mathrm{ft}$ along with an increase in recharge of 12 percent. These simulations were steady state and they assumed that the aquifer was at equilibrium with the new conditions for sea level and recharge. The simulations do not include the time it would take to reach that equilibrium. The projected changes in water levels under these scenarios are shown in figures 8 and 9 . The changes were calculated as the difference in simulated heads between the preliminary model (current conditions) and the two future scenarios. In addition, differences in the water budget were tabulated (appendix 2).

\section{Effects of Rise in Sea Level}

The simulated 3-ft rise in sea level increased groundwater levels from $<0.5$ to $3 \mathrm{ft}$, depending on location in the study area (fig. 8). Simulated rises in groundwater levels tapered off toward the discharge area in the simulated stream in Beaver Ponds Park. The simulated streamflow draining from Beaver Ponds Park increased by 34 percent as a result of an increase in the gradient between the stream and the elevated groundwater levels (appendix 2).

\section{Effects of Sea-Level Rise and Increased Recharge}

In the scenario with a 3 -ft rise in sea level and a 12-percent increase in recharge to glacial stratified deposits, the simulated groundwater levels rise as much as an additional 1 foot in parts of the study area (fig. 9). This indicates that increases in recharge could exacerbate problems that exist when groundwater levels are high from the rise in sea level. The simulated streamflow draining from Beaver Ponds Park increased by 57 percent over the baseline simulation (no increase in sea level or recharge) as a result of an increase in recharge and an increase in the gradient between the stream and the elevated groundwater levels. The simulated discharge to tidal and upland rivers and New Haven Harbor increased by about 1 cubic foot per second over the initial condition because recharge increases the volume of water in the system.

The City of New Haven is considering using enhanced groundwater recharge as a method of managing stormwater and water quality. However, the results of the scenarios for rise in sea level with additional recharge suggest that if the overall recharge rate to downtown New Haven increases substantially, it may exacerbate problems with high water tables.

\section{Limitations and Needs for Future Work}

The results of this preliminary study help us provide a framework for understanding the effects of projected rise in sea level and increased recharge on groundwater levels in New Haven and in other similar coastal areas. The results presented have significant limitations, however, that need to be recognized. First, the study was conducted with existing datasets and was designed to be a tool for testing hypotheses regarding the response of this aquifer to rise in sea level and changes in recharge. A complete analysis of the sensitivity of the model has not been conducted and the effects of boundary conditions have not been determined. The model simulations are relatively simplistic and can be improved with more data and detailed model representations. 


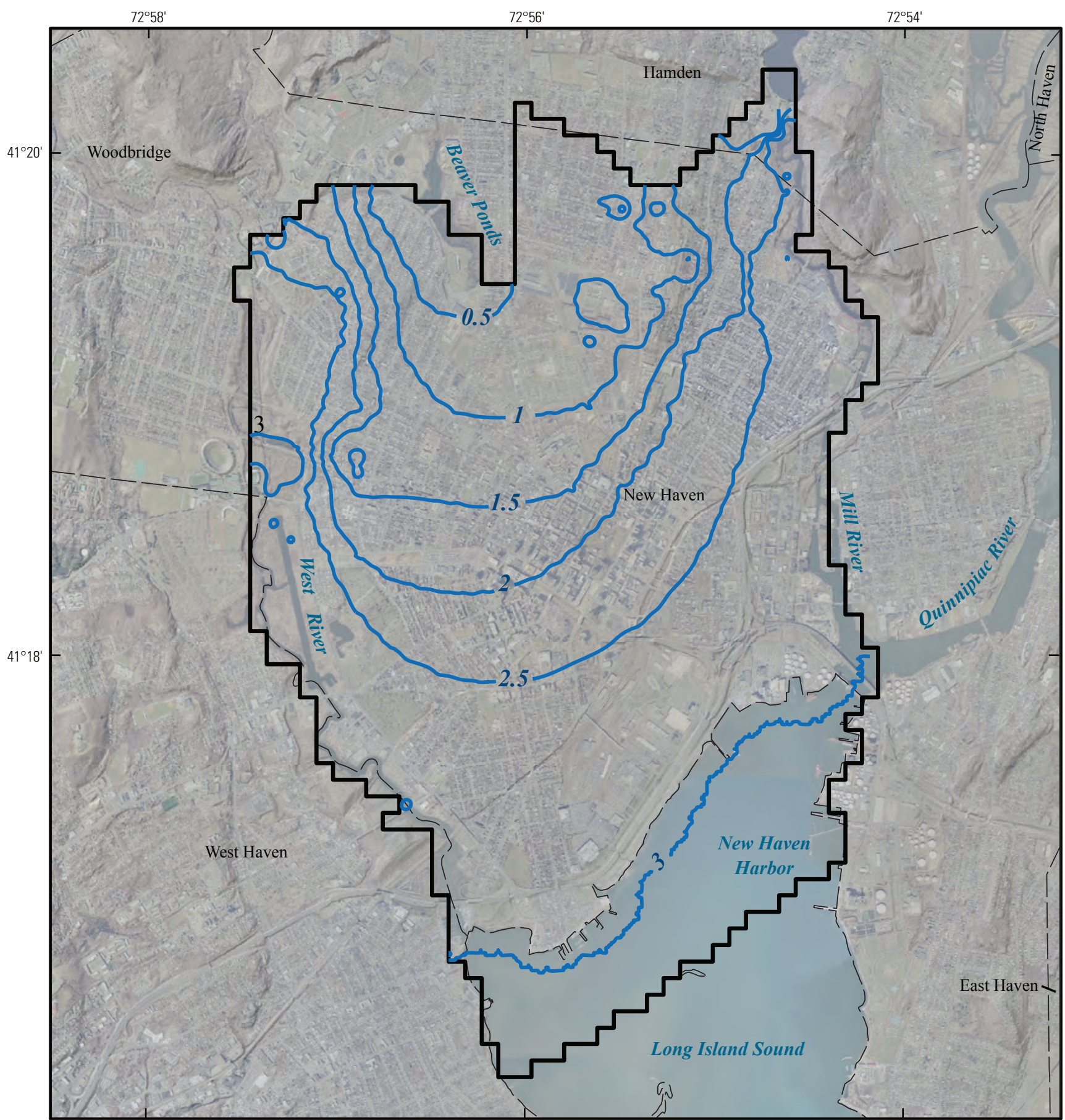

Base from U.S. Geological Survey and Aerometric Inc., Digital Orthophoto, 2008

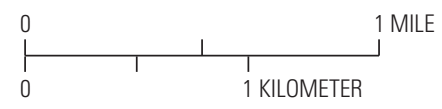

\section{EXPLANATION}

\section{Active area for the simulated model \\ - 0.5 - Difference in groundwater levels under a simulated 3-foot rise in sea level. \\ Contour interval is 0.5 foot}

Figure 8. Difference in groundwater levels between steady-state simulations for current conditions, and assuming a 3-foot rise in sea level. 


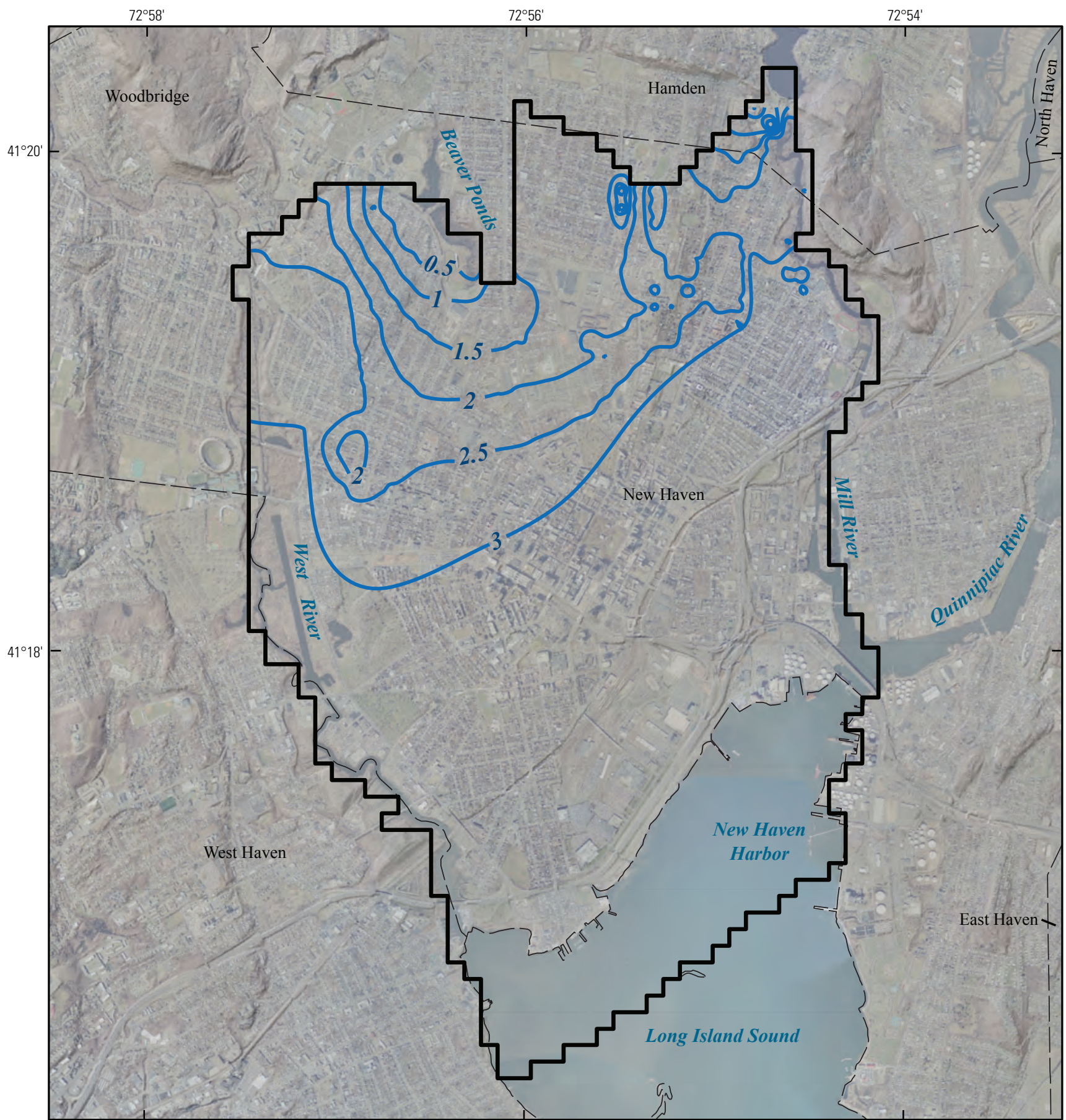

Base from U.S. Geological Survey and Aerometric Inc., Digital Orthophoto, 2008

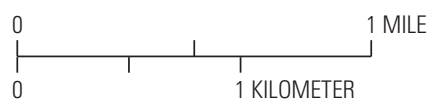

\section{EXPLANATION}

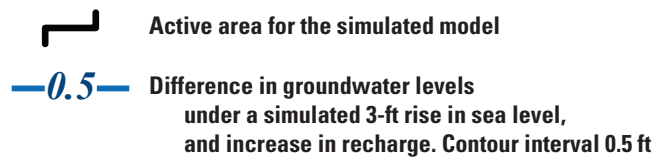

Figure 9. Difference in groundwater levels between steady-state simulations for current conditions and assuming a 3-foot rise in sea level and a 12-percent increase in groundwater recharge to glacial stratified deposits. 


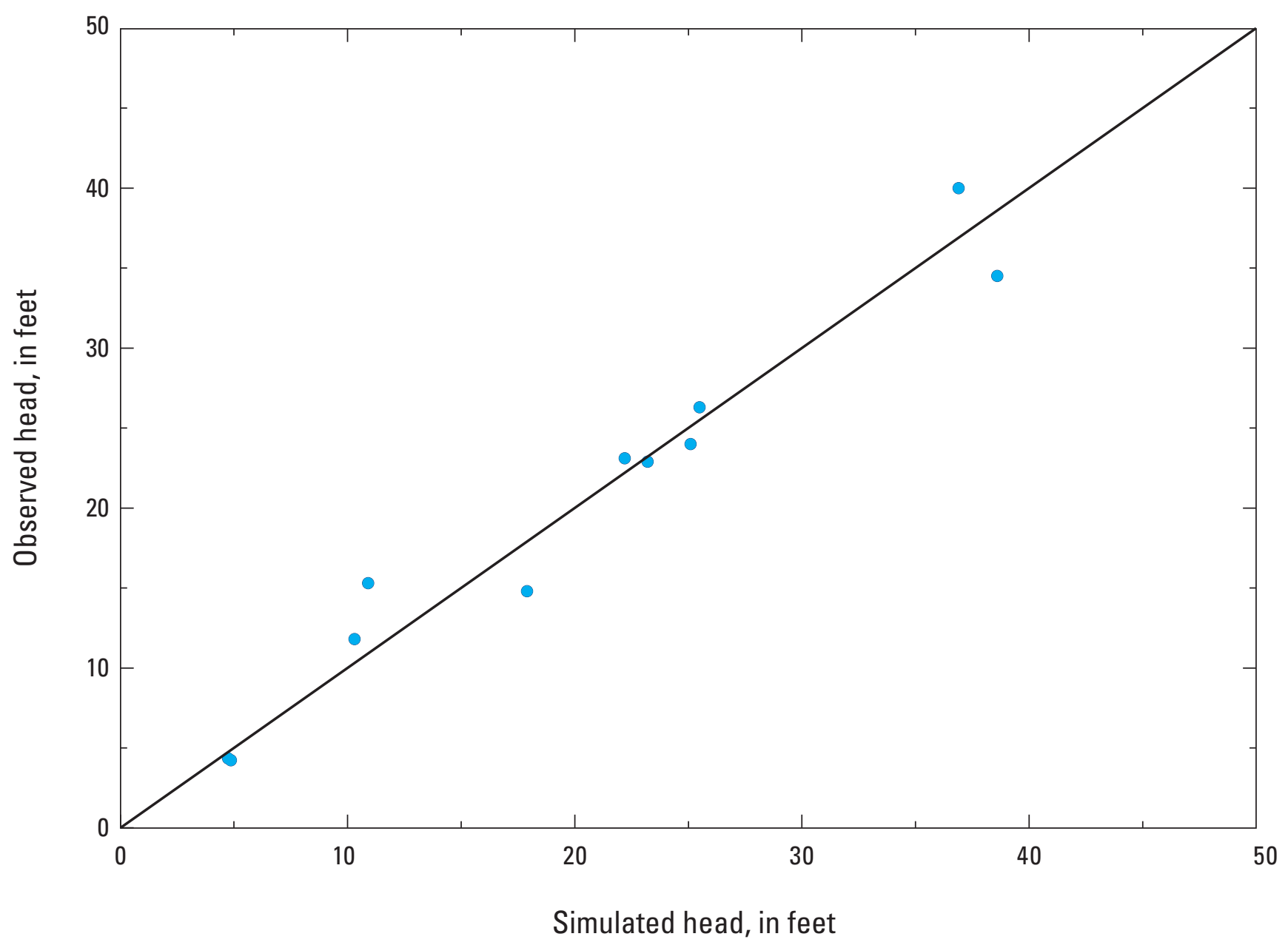

Figure 10. Simulated and mean measured hydraulic head 2009-2010, New Haven, Connecticut.

The following paragraphs briefly mention some of the limitations of this study and some of the information needed for reducing them.

The groundwater-flow simulations used MODFLOW-2000, which does not incorporate the effects of the variable density of seawater on groundwater flow in this coastal area of Connecticut. The simulations indicated that, with a 3-ft rise in sea level, the difference between the new higher water table and concurrent sea level is likely to decline, allowing seawater to intrude, thus thinning the freshwater lens, as described by Masterson and Garabedian (2007). The movement of seawater into the aquifer has implications for corroding underground infrastructure and may be exacerbated by current or future dewatering that might be necessary when sea level is elevated. Because these simulations assume that the configuration of the water table is not influenced by an interface between the freshwater and underlying saltwater, the use of SEAWAT (Guo and others, 2002) or another groundwater model that incorporates the different densities of seawater and freshwater could be useful to improve the simulations. Additionally, data on the current configuration of the boundary between freshwater and saltwater could be used to verify the model and assess the potential effect that rising sea level would have on the altitude of the freshwater/saltwater interface. These data could be obtained by using additional and deeper wells and (or) by geophysical methods, such as 2-dimensional resistivity or continuous resistivity, in order to identify the depth to the interface between freshwater and saltwater.

Recharge rates used in this model are not verified by measurement of discharge of groundwater from the aquifer, and therefore there are multiple combinations of recharge rates and hydraulic conductivity (non-unique solutions) that can match heads in the aquifer to observed data. 
New Haven is surrounded by a harbor and tidal rivers. Methods for measuring the discharge from the aquifer in tidal waters are limited. Over the long term, discharge from the aquifer should balance recharge, therefore, discharge data (and the recharge values inferred from those data) would improve the accuracy of the model by reducing the number of possible non-unique solutions.

Direct measurement of aquifer discharge to non-tidal and tidal waters can be made with measurements of the stream that drains Beaver Ponds Park and the use of seepage meters in rivers, tidal creeks, and estuaries. Indirect measurements of the submarine groundwater discharge can be measured by using geochemical tracers such as radium (Abraham and others, 2003; Crusius and others, 2005) or by using heat as a tracer (Henderson and others, 2009). Measurements of discharge would further constrain the estimates of horizontal hydraulic conductivity that were identified as sensitive parameters.

Recharge rates in urban areas are poorly understood. Lerner (2002) describes some of the complexities involved in understanding urban recharge: the high density of impervious surfaces and the associated methods of disposing of stormwater, the constant potential for leaking water mains and sanitary sewers, and differences in evapotranspiration. Further information on the age and condition of New Haven water and sewer systems as well as on the differences in disposing of stormwater in different areas of the city would improve recharge estimates.

Although simulated water levels matched mean water levels from 11 observation wells reasonably well (fig. 10), longer term data on water levels from a greater geographic area would likely improve the model and reduce uncertainty in the sensitivity of parameters. The present study has no information on the water table from two till-covered, bedrock-cored hills in the northern part of the study area, from the western areas of New Haven between downtown and the West River, and from the deeper parts of the aquifer. In addition, longer-term measurements of groundwater levels are needed in order to better determine average conditions.

The preliminary model was run as steady state, although there are several parameters that are changing — sea level has been rising, as have groundwater levels. Transient simulations would allow for simulation of these effects and for greater understanding of the amount of time required for water levels and the position of the interface between freshwater and saltwater to adjust to changes in sea level and recharge.

\section{Summary and Conclusions}

The U.S. Geological Survey, in cooperation with Yale University, conducted a preliminary study of the effects of a rise in sea level on groundwater levels in New Haven, Connecticut. There is concern in New Haven that rising groundwater levels, caused by rising sea levels, may inundate the underground infrastructure such as basements of buildings and utilities. In addition, there is concern about intrusion of seawater in areas near the coast with the implication that infrastructure below the water table may be subject to corrosion if the interface between freshwater and saltwater were to rise.

Globally, sea level rose about 0.56 feet (ft) (170 millimeters $(\mathrm{mm})$ ) during the 20th century. Since the 1960s, sea level at Bridgeport, Conn., rose at a rate of $0.008 \mathrm{ft}(2.56 \mathrm{~mm} \pm 0.58 \mathrm{~mm})$ per year, or about $0.38 \mathrm{ft}(115 \mathrm{~mm})$. The rate of rise in sea level in Connecticut is greater than eustatic rise in sea level because of coastal subsidence. Under predicted scenarios for global climate change, sea level is projected to continue to rise to as much as $2.92 \mathrm{ft}$ above current levels ( $897 \mathrm{~mm})$ by 2080 . Rise in sea level may be greater than this amount depending on the future melting of alpine and continental glaciers.

A preliminary model of groundwater flow was developed using MODFLOW-2000 in order to test hypotheses regarding the effects of rise in sea level and of increased recharge on groundwater levels. Three models were constructed:

- A preliminary steady-state model, which was compared to groundwater levels measured in 11 wells from October 2009 to June 2010.

- A preliminary steady-state simulation in which projected sea level was simulated to be $3 \mathrm{ft}$ higher than current (2011) New Haven mean sea level by adjusting constant head cells representing New Haven Harbor and by adjusting of the surface elevation of the simulated tidal reaches of the West River and the Mill Rivers.

- A preliminary steady-state simulation with a 3-ft rise in sea level together with a 12-percent increase in recharge to glacial stratified deposits. 
Data on groundwater levels, temperature, and specific conductance were collected at 13 wells during October 2009June 2010. Eight of the wells had continuous recorders of water level and temperature during at least part of the measurement period. At most of the wells, water levels fluctuated seasonally within a small range during the study period. Groundwater temperatures varied seasonally, but were higher than typical for Connecticut, and may have reflected the influence of the urban setting. Specific conductance was elevated in many of the wells, indicating the influence of urban activities or influence of seawater in Long Island Sound.

The results of the preliminary groundwater modeling simulations showed that, with a 3 - $\mathrm{ft}$ rise in sea level and with no increase in recharge, the simulated rise in groundwater levels in New Haven ranged from $3 \mathrm{ft}$ at the shore at New Haven Harbor to less than $0.5 \mathrm{ft}$ in some of the northern parts of the modeled area. Simulated flows from the stream leaving Beaver Ponds Park (the only stream simulated to remain above sea level) increased 34 percent due to the nearby rise in groundwater levels and the resulting increased gradient. The simulated difference between the groundwater levels and the adjusted sea level declined, indicating that, under a rise in sea level, depth to the saltwater interface may also decline.

The additional steady-state simulation of a $3-\mathrm{ft}$ rise in sea level and a 12-percent increase in recharge to the glacial stratified deposits exacerbated the effects of rise in sea level because groundwater levels rise as recharge is increased. In some areas, simulated groundwater levels were as much as an additional 1 foot higher than under the scenario with just a 3-ft rise in sea level.

The simulations undertaken for this study were preliminary, and numerous limitations were apparent. The following kinds of information are needed to improve this model as a prediction tool:

- A variable-density groundwater-flow algorithm to simulate changes to the location and depth of the interface between freshwater and saltwater should be included in the model. Collecting additional data to determine the location of the interface could help verify simulations.

- This study assumed that the study area had been at or near a steady-state condition during the decades since extensive groundwater withdrawals ceased in the 1970s. The future scenarios used in this study also assumed that the model had reached a steady state after a change to recharge or sea level had occurred. A transient simulation would allow for greater understanding of the amount of time required for water levels and the position of the interface between freshwater and saltwater to adjust to changes in sea level and recharge.

- Collecting additional data in order to determine discharge from the aquifer would be useful in constraining the number of non-unique solutions to the groundwater-flow model and constrain some of the more sensitive parameters. Discharge from the stream draining Beaver Ponds Park could be measured, seepage and groundwater temperature in discharge areas could be measured, and geochemical tracers in tidal rivers could be used.

- Water-level data from a long-term dataset, in addition to a greater number of wells at different locations and depths in the aquifer would be necessary to improve the model.

The results of this preliminary investigation indicate that under two scenarios for rise in sea level, increases in groundwater levels in coastal areas such as New Haven can be expected. A substantial part of the study area has a land surface altitude of less than $30 \mathrm{ft}$ above NGVD 29. Under the scenarios for rise in sea level simulated in this study, basements of buildings and conduits for some underground utilities may be flooded. Some of the aging storm drains and sanitary sewers may intercept the water table and act as a conduit for groundwater flow. Results from the simulations indicated that even areas with a water-table altitude of 17 to $24 \mathrm{ft}$ above sea level had simulated increases in the water table due to rise in sea level and an increase in recharge.

The results of the simulation of rise in sea level and increased recharge also have implications for disposal of stormwater. In recent years, low-impact development practices have been implemented to dispose of stormwater by infiltrating as much water as possible. These practices can lead to improvements in water quality and overland stormwater peak discharge. However, largescale implementation of these practices in a coastal area may exacerbate the problem of high groundwater levels caused by a rise in sea level, where infrastructure may be located at an altitude that may be inundated. As an example, some shoreline seasonal communities have onsite wastewater systems where suitability based on depth to groundwater is currently marginal.

The hydrology of the New Haven area is complex, and a calibrated variable-density transient numerical groundwater flow and transport model would be required to understand the interaction of all the significant factors that affect groundwater levels and the depth to the interface between freshwater and saltwater. A future enhanced model could be used to evaluate with more accuracy and certainty the alternative scenarios for rise in sea level and in recharge, particularly the potential for a greater rise in sea level by the end of the 21 st century, and to identify those areas of New Haven where infrastructure may be at greatest risk from rising levels of groundwater. 


\section{References Cited}

Abraham, D.M., Charette, M.A., Allen, M.C., Rago, A., and Kroeger, K.D., 2003, Radiochemical estimates of submarine groundwater discharge to Waquoit Bay, Massachusetts: The Biological Bulletin, v. 205, p. 246-247.

Barlow, P.M., 2003, Ground water in freshwater-saltwater environments of the Atlantic Coast: U.S. Geological Survey Circular $1262,113 \mathrm{p}$.

Bjerklie, D.M., Trombley, T.J., and Viger, R.J., 2011, Simulations of historical and future trends in snowfall and groundwater recharge for basins draining to Long Island Sound: Earth Interactions, v. 15, no. 34, December 2011, p. 1-35.

Brown, J.S., 1925, A study of coastal ground water, with special reference to Connecticut: U.S. Geological Survey Water-Supply Paper 537, $101 \mathrm{p}$.

Brown, J.S., 1928, Ground water in the New Haven area, Connecticut: U.S. Geological Survey Water-Supply Paper 540, 206 p.

Cooper, H.H., Jr., 1964, A hypothesis concerning the dynamic balance of fresh water and salt water in coastal aquifer: U.S. Geological Survey Water-Supply Paper 1613-C, p. 1-12.

Crusius, J., Koopmans, D., Bratton, J.F., Charette, M.A., Kroeger, K.D., Henderson, P., Ryckman, L., Halloran, K.,and Colman, J.A., 2005, Submarine groundwater discharge to a small estuary estimated from radon and salinity measurements and a box model: Biogeosciences Discussions, v. 2, no. 1-35, 28 p.

Donnelly, J.P., Cleary, P., Newby, P., and Ettinger, R., 2004, Coupling instrumental and geological records of sea-level change: Evidence from southern New England of an increase in the rate of sea-level rise in the late 19th century: Geophysical Research Letters v. 31, L0520, p. 1-4.

Flint, R.F., 1965, The surficial geology of the New Haven and Woodmont Quadrangles: State Geological and Natural History Survey of Connecticut Quadrangle Report 18, 42 p.

Gehrels, W.R., Kirby, J.R., Prokoph, A., Newnham, R.M., Achterberg, E.P., Evans, E.H., Black, S., and Scott, D.B., 2005, Onset of recent rapid sea-level rise in the western Atlantic Ocean: Quaternary Science Reviews, v. 24, no. 18-19, p. 2083-2100.

Gornitz, V., Couch, S., and Hartig, E.K., 2002, Impacts of sea level rise in the New York City metropolitan area: Global and Planetary Changes, v. 32, p. 61-88.

Gornitz, V., Hale, S., Larsen, K., Nevine, N., Rosenzweig, C., and Sacks, L., 2004, Bracing for climate change in the Constitution State-What Connecticut could face Environmental Defense Fund, accessed at http://www.edf.org/ documents/3504_ct-climate_09_view.pdf.

Gornitz, V., and Rosenzweig, C., 2009, Severe storms and sea level rise in New York City: Water Resources Impact, v. 11, no. 1, p. $10-14$.

Grady, S.J., 1993, Analysis of nonpoint source ground-water contamination in relation to land use-Chapter B, Effects of land use on water quality in stratified-drift aquifers in Connecticut: U.S. Geological Survey Open-File Report 91-200, 87 p.

Guo, Weixing, and Langevin, C.D., 2002, User's Guide to SEAWAT-A computer program for simulation of three-dimensional variable-density ground-water flow: Techniques of Water-Resources Investigations, book 6, chap. A7, 77 p.

Haeni, F.P., and Sanders, J.E., 1974, Contour map of the bedrock surface, New Haven-Woodmont quadrangle, Connecticut: U.S. Geological Survey Miscellaneous Field Studies Map MF-557-A, scale 1:24,000.

Harbaugh, A.W., Banta, E.R., Hill, M.C., and McDonald, M.G., 2000, MODFLOW-2000, The U.S. Geological Survey modular ground-water model-User guide to modularization concepts and the ground-water flow process: U.S. Geological Survey Open-File Report 00-92, 121 p.

Henderson, R.D., Day-Lewis, F.D., and Harvey, C.F., 2009, Investigation of aquifer-estuary interaction using wavelet analysis of fiber-optic temperature data: Geophysical Research Letters, v. 36, L06403, 6 p.

Holgate, S.J., and Woodworth, P.L., 2004, Evidence for enhanced coastal sea level rise during the 1990s: Geophysical Research Letters, no. 31, L07305, 4 p. 
Intergovernmental Panel on Climate Change (IPCC), 2007, Climate Change 2007-The physical science basis, Contributions of working group 1 to the Fourth Assessment Report of the IPCC: Cambridge, UK, Cambridge University Press, p. 996.

Kirshen, P., Watson, C., Douglas, E., Gontz, A., Lee, J., and Tian, Y., 2008, Coastal flooding in the northeastern United States due to climate change; Assessment of climate change, impacts, and solutions in the northeast United States: Mitigation and Adaptation Strategies for Global Change, v. 13, no. 5-6, p. 437-451.

Lerner, D.N., 2002, Identifying and quantifying urban recharge-A review: Hydrogeology Journal, v. 10, p. 143-152.

Masterson, J.P., 2004, Simulated interaction between freshwater and saltwater and effects of ground-water pumping and sealevel change, Lower Cape Cod aquifer system, Massachusetts: U.S. Geological Survey Scientific Investigations Report 2004-5014, $72 \mathrm{p}$.

Masterson, J.P., and Garabedian, S.P., 2007, Effects of sea-level rise on ground water flow in a coastal aquifer system: Groundwater, v. 45, no. 2, p. 209-217.

Mazzaferro, D.L., 1973, Hydrogeologic data for the Quinnipiac River basin, Connecticut: Connecticut Water Resources Bulletin $26,54 \mathrm{p}$.

National Oceanic and Atmospheric Administration, 2011, Mean sea level trend-8461490 New London, Connecticut: National Oceanic and Atmospheric Administration, accessed November 28, 2011, at http://tidesandcurrents.noaa.gov/sltrends/sltrends station. shtml?stnid=8461490.

Nicholls, R.J., 1995, Coastal megacities and climate change: GeoJournal, v. 37, no. 3, p. 369-379.

Nydick, K.R., Bidwell, A.B., Thomas, E., and Varekamp, J.C., 1995, A sea-level rise curve from Guilford, Connecticut, USA: Marine Geology, v. 124, no. 1-4, p. 137-159.

Oude Essink, G.H.P., van Baaren, E.S., and de Louw, P.G.B., 2010, Effects of climate change on coastal groundwater systems: A modeling study in the Netherlands: Water Resources Research, v. 46, 16 p.

Overpeck, J.T., Otto-Bliesner, B.L., Miller, G.H., Muhs, D.R., Alley, R.B., and Kiehl, J.T., 2006, Paleoclimatic evidence for future ice-sheet instability and rapid sea-level rise: Science, v. 311, no. 6768 , p. 1747-1750.

Rozell, D.J., and Wong, T., 2010, Effects of climate change on groundwater resources at Shelter Island, New York State, USA: Hydrogeology Journal, v. 18, p. 1657-1665.

Stone, J.R., Schafer, J.P., London, E.H., DiGiacomo-Cohen, Mary, Lewis, R.S., and Thompson, W.B., 2005, Quaternary geologic map of Connecticut and Long Island Sound Basin, with a section on sedimentary facies and morphosequences of glacial meltwater deposits by B.D. Stone: U.S. Geological Survey Scientific Investigations Map 2784, 2 sheets, one pamphlet, scale 1:125,000.

Stone, J.R., Schafer, J.P., London, E.H., and Thompson, W.B., 1992, Surficial materials map of Connecticut: U.S. Geological Special Map, 2 sheets, scale 1:125,000.

Van de Plassche, O., Van der Borg, K., and de Jong, A.F.M., 1998, Sea level-climate correlation during the past 1400 years: Geology, v. 26, no. 4, p. 319-322.

Varekamp, J.C., Thomas, E., and Van de Plassche, O., 1992, Relative sea-level rise and climate change over the last 1500 years: Terra Nova, v. 4, no. 3, p. 293-304.

Wada, Y., van Beek, P.H., van Kempen, C.M., Reckman, W.T.M., Slavek, V., and Bierkens, F.P., 2010, Global depletion of groundwater resources: Geophysical Research Letters, v. 37, no. L20402, 5 p.

Watson, T.A., Werner, A.D., and Simmons, C.T., 2010, Transience of seawater intrusion in response to sea level rise: Water Resources Research, v. 46, 10 p.

Werner, A.D., and Simmons, C.T., 2009, Impact of sea-level rise on sea water intrusion in coastal aquifers: Ground Water, v. 47, no. 2, p. 197-204.

Yechieli, Y., Shalev, E., Wollman, S., Kiro, Y., and Kafri, U., 2010, Response of the Mediterranean and Dead Sea coastal aquifers to sea level variations: Water Resources Research, v. 46, 11 p. 
THIS PAGE INTENTIONALLY LEFT BLANK 


\section{Appendix 1. Geologic Setting and History of Rise in Sea Level}

\section{Figures}

1-1. Map showing surficial materials of the New Haven, Connecticut, area ..........................31

1-2. Schematic diagram of the boundary of glacial Lake Connecticut and the margin of the ice sheet during late Wisconsinan times $(19,000$ years ago)...

1-3. Schematic diagram of deltaic deposits prograding into a glacial lake, including topset, foreset, and bottomset deposits .

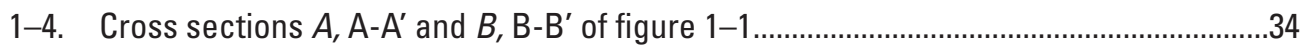




\section{Appendix 1. Geologic Setting and History of Rise in Sea Level}

The City of New Haven is on the coast of Connecticut, and its hydrology and groundwater conditions are controlled by the geologic framework of the region. The New Haven area, at the southern end of the Central Lowland of Connecticut, is underlain by early Mesozoic (late Triassic) arkosic sedimentary rocks of the New Haven Arkose locally intruded by (early Jurassic) igneous rock (West Rock dolerite) (Rodgers, 1985). The New Haven Arkose is the oldest sedimentary unit deposited in the Hartford Rift Basin. In most places these rock units strike north-northeast and dip gently $\left(15-20^{\circ}\right)$ east-southeast as a result of downdropping along major normal faults at the eastern edge of the rift basin. The more resistant igneous rock units stand as topographic highs such as East Rock and West Rock ridges (fig. 1-1). Bedrock in the New Haven area crops out locally at the land surface and is as much as 500 feet ( $\mathrm{ft}$ ) below land surface in a buried valley beneath the city. The bedrock surface has as much as $1,000 \mathrm{ft}$ of relief with altitudes ranging from greater than $400 \mathrm{ft}$ above National Geodetic Vertical Datum of 1929 (NGVD 29) to greater than $550 \mathrm{ft}$ below NGVD 29. Weathered bedrock occurs in some places at the top of the bedrock surface beneath the relatively nonweathered glacial deposits, and it represents the remnants of a formerly (preglacial) widespread mantle of weathered rock. The main features of the present landscape, including the major hills and valleys and the uplands and lowlands, were probably present in that preglacial landscape.

During the last (late Wisconsinan) glaciation, a sector of the Laurentide ice sheet covered all of Connecticut, and had reached its maximum extent on Long Island, New York, by 28,000 to 23,000 years ago. Ice movement across Connecticut during the advance was dominantly from north-northwest to south-southeast, but during retreat a prominent ice lobe developed in and adjacent to the Central Lowland of Connecticut (Stone and others, 2005). Most ice-movement directions indicated by drumlins (thick-till hills) and striations and grooves on the bedrock surface in the New Haven area record south-southwesterly directions due to that lobation of the ice.

Two basic types of glacial deposits occur in the New Haven area: glacial till and glacial meltwater deposits. Till was laid down beneath the advancing ice sheet (lodgement till) or melted out of glacial ice during retreat (ablation till). Till comprises a heterogeneous (unsorted) mixture of boulders, cobbles, sand, silt, and clay of variable thickness. In the New Haven area, most till is red-brown, similar to the color of the New Haven Arkose from which it was derived. Locally, near the igneous rock ridges, till derived from that rock is more grayish-brown in color. Most of the material contained within thick till hills (drumlins), such as Marsh Hill in West Haven (fig. 1-1), is older (probably Illinoian) till from an earlier glaciation. Thin till (less than $15 \mathrm{ft}$ in thickness) overlies bedrock in most places and generally underlies glacial meltwater deposits in the valleys.

Glacial meltwater deposits were laid down during the retreat of the late Wisconsinan ice sheet. Meltwater picked up rock debris carried by the ice and deposited much of it a short distance beyond the ice margin. The sediments are sorted, stratified layers of gravel, sand, silt, and clay, which accumulated in glacial streams and in large and small glacial lakes that were fed by meltwater. Because meltwater flowed primarily in valleys during deglaciation, meltwater deposits are concentrated in those valleys and in some places are more than $100 \mathrm{ft}$ in thickness.

Most of the glacial meltwater deposits in Connecticut were laid down in glacial lakes, both large and small. In the New Haven area, glacial meltwater deposits include glaciofluvial gravels and sands, glaciodeltaic sandy gravel and sand, and lake-bottom silt and clay that were graded to or deposited in a large glacial lake that occupied the present basin of Long Island Sound during retreat of the last ice sheet. Figure 1-2 shows the position of the ice margin and lake in the New Haven area and figure 1-3 shows a cross-sectional view of delta progradation. Deglaciation of the Long Island Sound basin was entirely dominated by the presence of glacial Lake Connecticut (Stone and others, 1985), which was impounded in the basin behind the Harbor Hill-Fishers Island-Charlestown recessional moraine. Formation of the lake began about 22,000 years ago when the ice front began to recede from the recessional moraine position. Meltwater was impounded in the expanding long, narrow basin between the moraine to the south and the retreating ice margin to the north. Water levels in the lake were controlled by a spillway across the lowest point on the recessional moraine, at the place that is today called The Race. The spillway slowly lowered by erosion during the life of the lake. As deglaciation progressed, the topography of the Central Lowland produced a lobe of ice extending southward from New Haven that lingered the longest in the lake. As this ice lobe retreated out of the lake, a complex of deltas was built in West Haven, in New Haven, and in East Haven; the lake then stood at about $33 \mathrm{ft}$ above present sea level. These deltas are extensive both on land and offshore. Thick varved (alternating layers of silt and clay) lake-bottom sediments underlie the southern parts of deltas on land and occur offshore where, in the deep central part of the lake basin, they are more than 300-ft thick. Much of the varved lake-clay section settled out in the lake concurrent with deposition of the New Haven area deltas (Lewis and Stone, 1991). During this time, the level of glacial Lake Connecticut continued to lower, due to erosion at the spillway. As shoreward portions of the lakebed were subaerially exposed, streams locally entrenched older, higher-level delta deposits and redeposited coarser material farther out into the lake basin (Stone and others, 2005).

Glacial meltwater sediments underlying New Haven and offshore are deltaic and consist of gravelly flat-lying topset beds unconformably overlying sandy, dipping forest beds; foreset bedding dips generally southerly, and grain-sizes are generally coarser upward in the section and to the north in map view. The topset-foreset contact in the New Haven delta, which records the 


\section{Select the attachment for larger image}

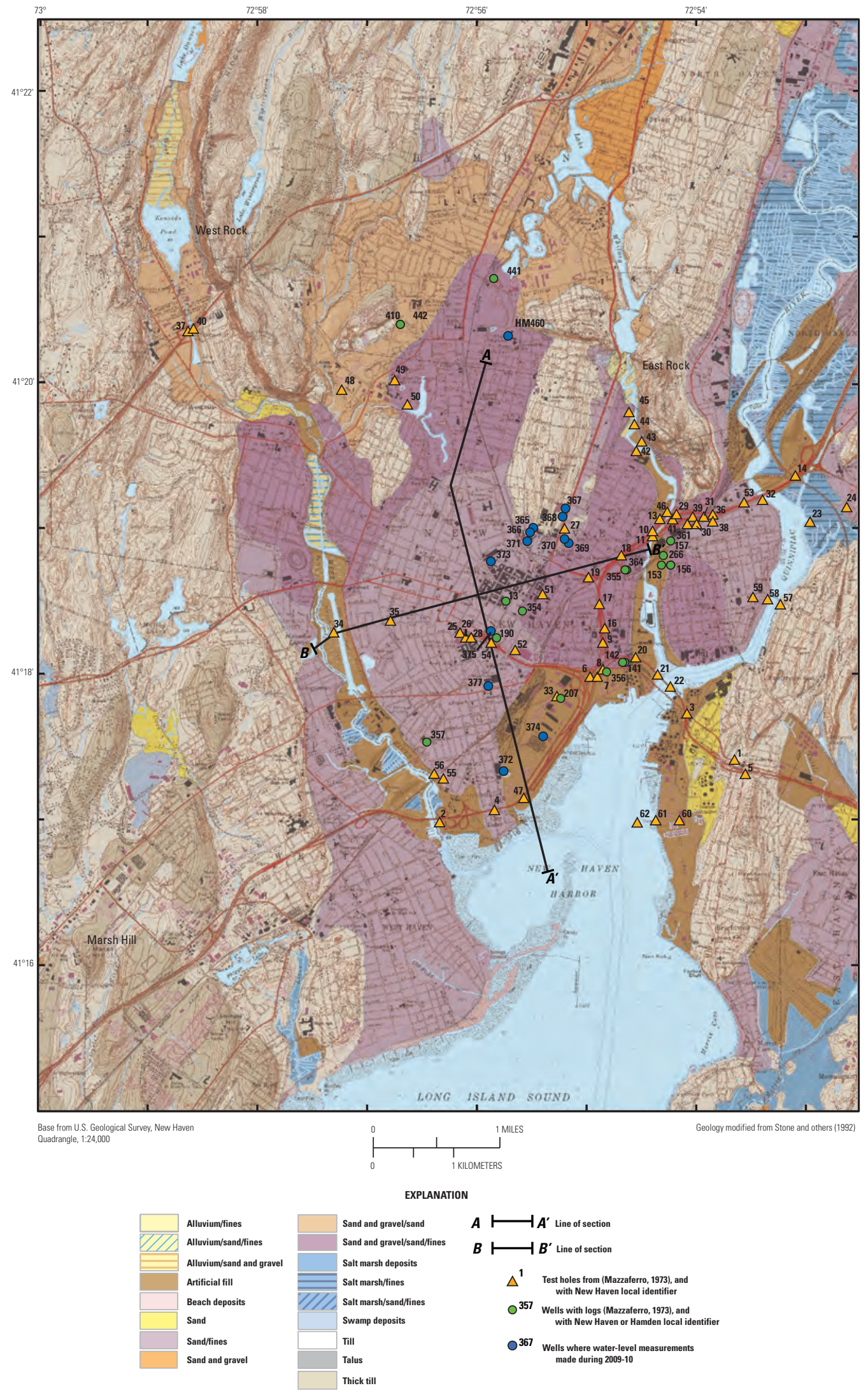

Figure 1-1. Surficial materials of the New Haven, Connecticut, area. 


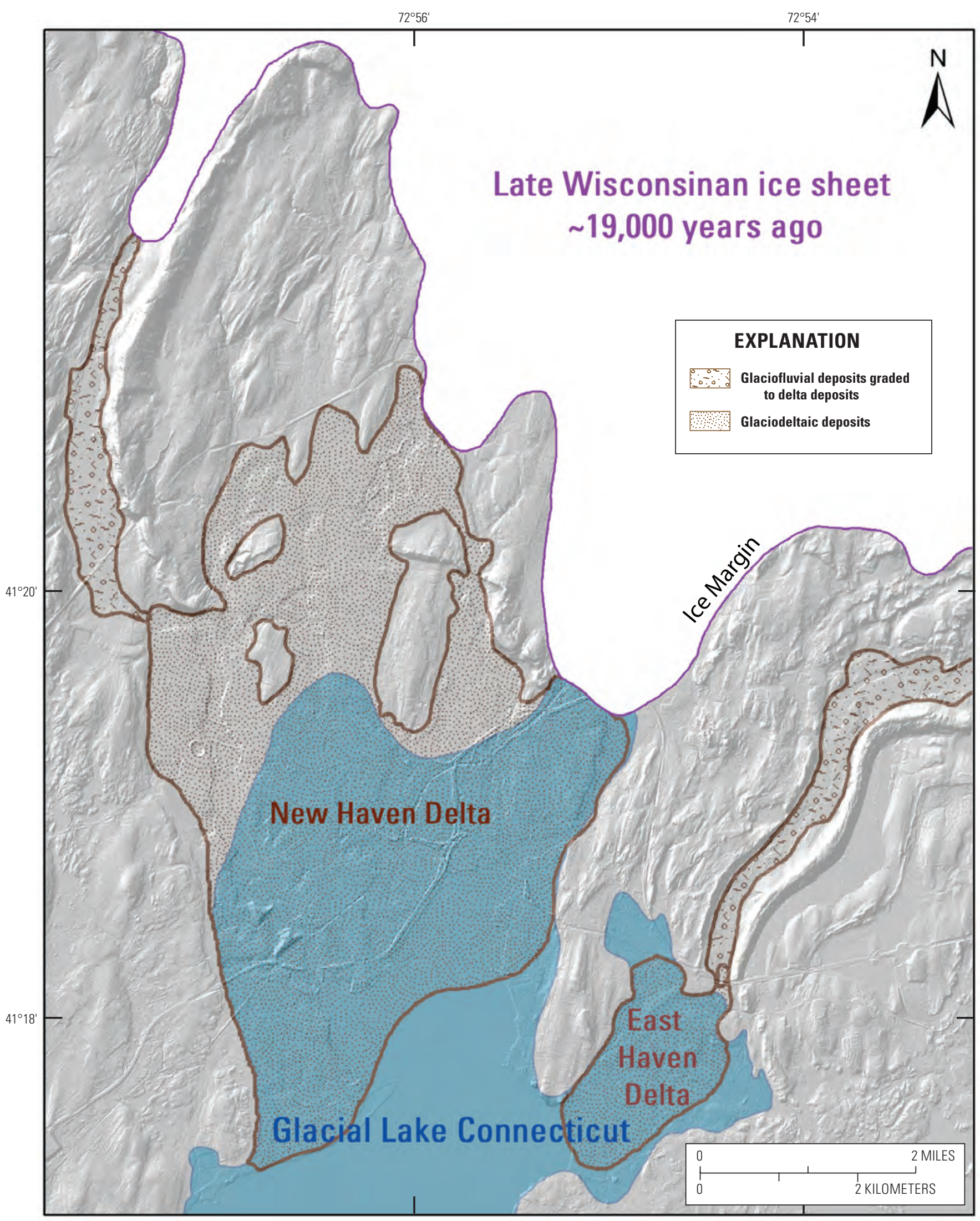

Figure 1-2. Schematic diagram of the boundary of glacial Lake Connecticut and the margin of the ice sheet during late Wisconsinan times $(\sim 19,000$ years ago). 


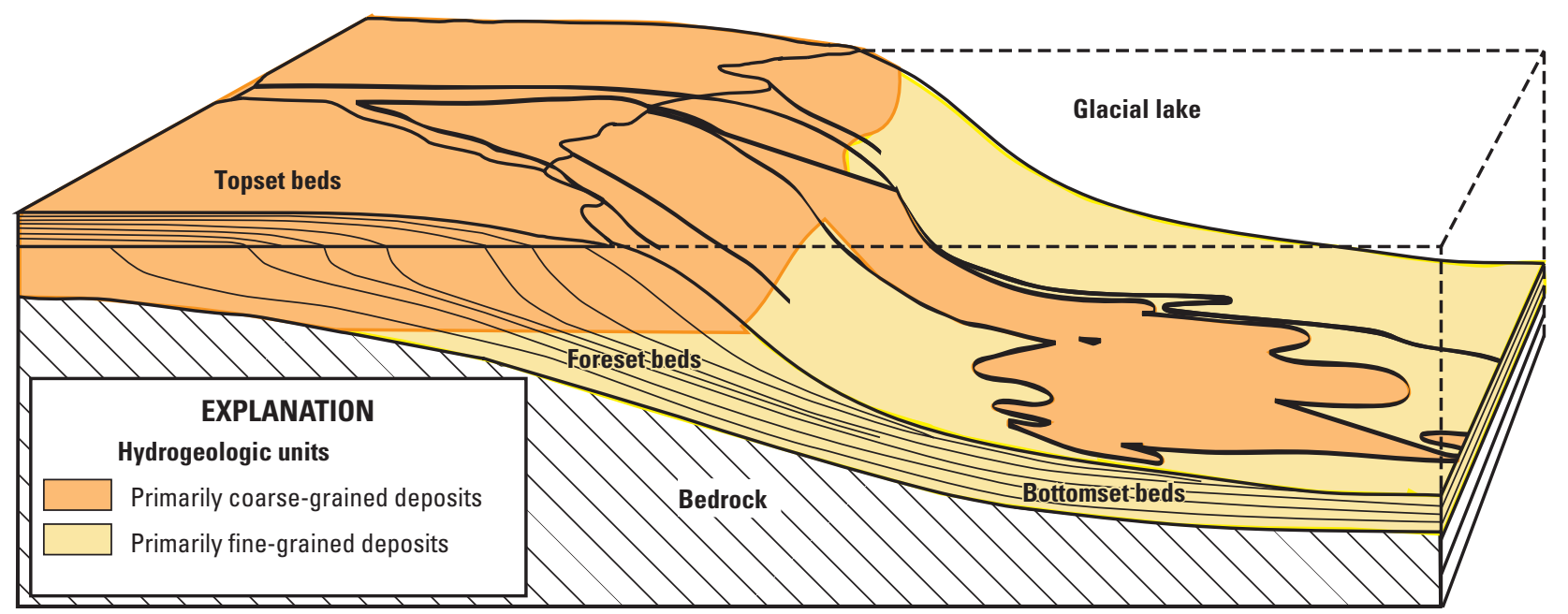

Figure 1-3. Schematic diagram of deltaic deposits prograding into a glacial lake, including topset, foreset, and bottomset deposits (Modified from Smith and Ashley, 1985).

water level of the lake at the time of deposition, lies at approximately $33 \mathrm{ft}$ in altitude and was exposed in the excavation for the Yale Bowl (Ward, 1920). As much as $200 \mathrm{ft}$ of varved silt and clay underlie the deltaic sediment in the southern part of the area.

The onset of postglacial conditions in Connecticut was time-transgressive, beginning several thousand years earlier in the southern part of the State than in northern parts. Early postglacial deposits in the New Haven area include stream-terrace deposits that were laid down on incised terraces cut into the New Haven delta as glacial Lake Connecticut lowered, and talus deposits that largely accumulated at the base of steep bedrock cliffs during the harsh periglacial condition following retreat of the ice sheet. Floodplain alluvium began to accumulate as stream base levels became stabilized following glacio-isostatic uplift, and salt-marsh deposits have accumulated mostly during the past 4,000 to 5,000 years as rising sea level has drowned former floodplains along the Quinnipiac River and the West River (fig. 1-1). Beach deposits, which are generally thin and overlie glacial sediments, have accumulated along the modern shoreline. In the Long Island Sound basin, significant postglacial events include the drainage of glacial Lake Connecticut and the subsequent rise in sea level. Between these events was a time of subaerial exposure of the drained lake bed, during which time it was entrenched by streams draining from the north, south, and westward from the Hudson Valley across Long Island Sound to The Race. The sea entered Long Island Sound via this channel system when eustatic sea level began to rise significantly by about 18,000 years ago (Fairbanks, 1989; Bard and others, 1990) and before glacio-isostatic rebound began. The static sea level reached as high as about $16 \mathrm{ft}(5 \mathrm{~m})$ below present level before lowering again when glacio-isostatic rebound began about 16,500 years ago. During the time of maximum uplift, the rate of rise of eustatic sea level matched the rate of uplift, and a stable sea level was maintained in Long Island Sound at about $131 \mathrm{ft}(40 \mathrm{~m})$ below present level. This condition existed for about 4,000 years, from about 16,000 to about 12,000 years ago (Stone and others, 2005). Once the rate of rebound slowed, sea level has risen steadily into modern times (Varekamp and others, 1992; Nydick and others, 1995; Van de Plassche and others, 1998). Most recently, human activities have resulted in the placement of fill and debris in many areas, particularly in estuarine channels and near shore areas, as land was built up and leveled for the expansion of the city of New Haven.

The deglacial and postglacial conditions described above have resulted in the distribution of surficial materials beneath New Haven (shown in figs. 1-1 and 1-4). In general, the glaciodeltaic meltwater sediments coarsen upward and to the north, and consist of sandy, southerly dipping delta foreset beds overlain by gravelly delta topset beds. Glaciodeltaic sediments overlie thick varved silt and clay in the southern part of the mapped area. 
喜 -

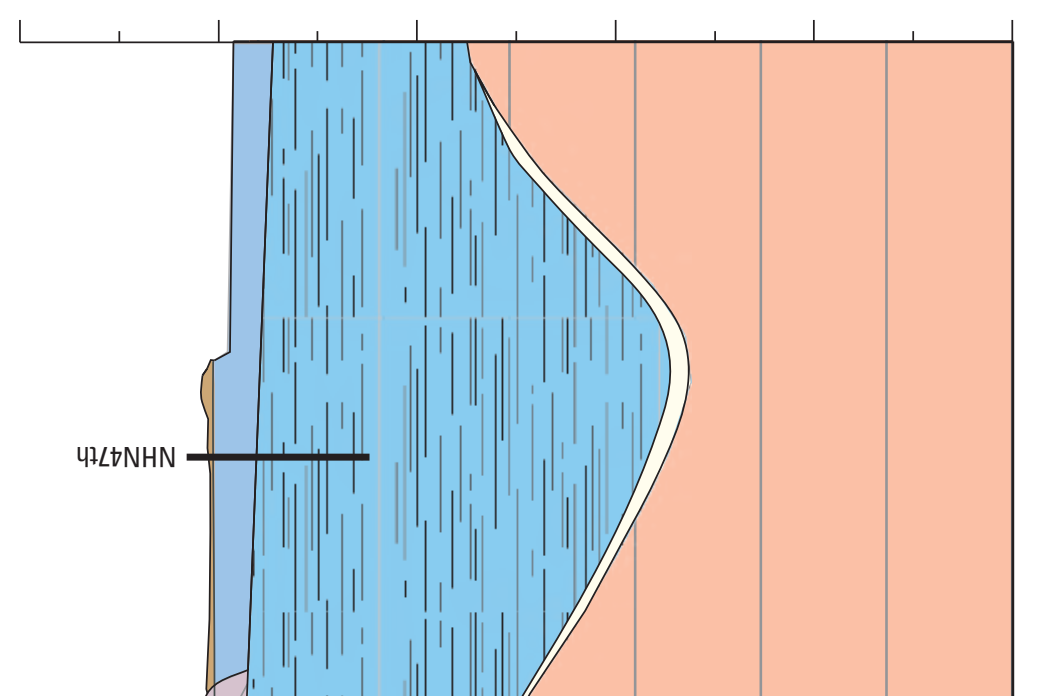



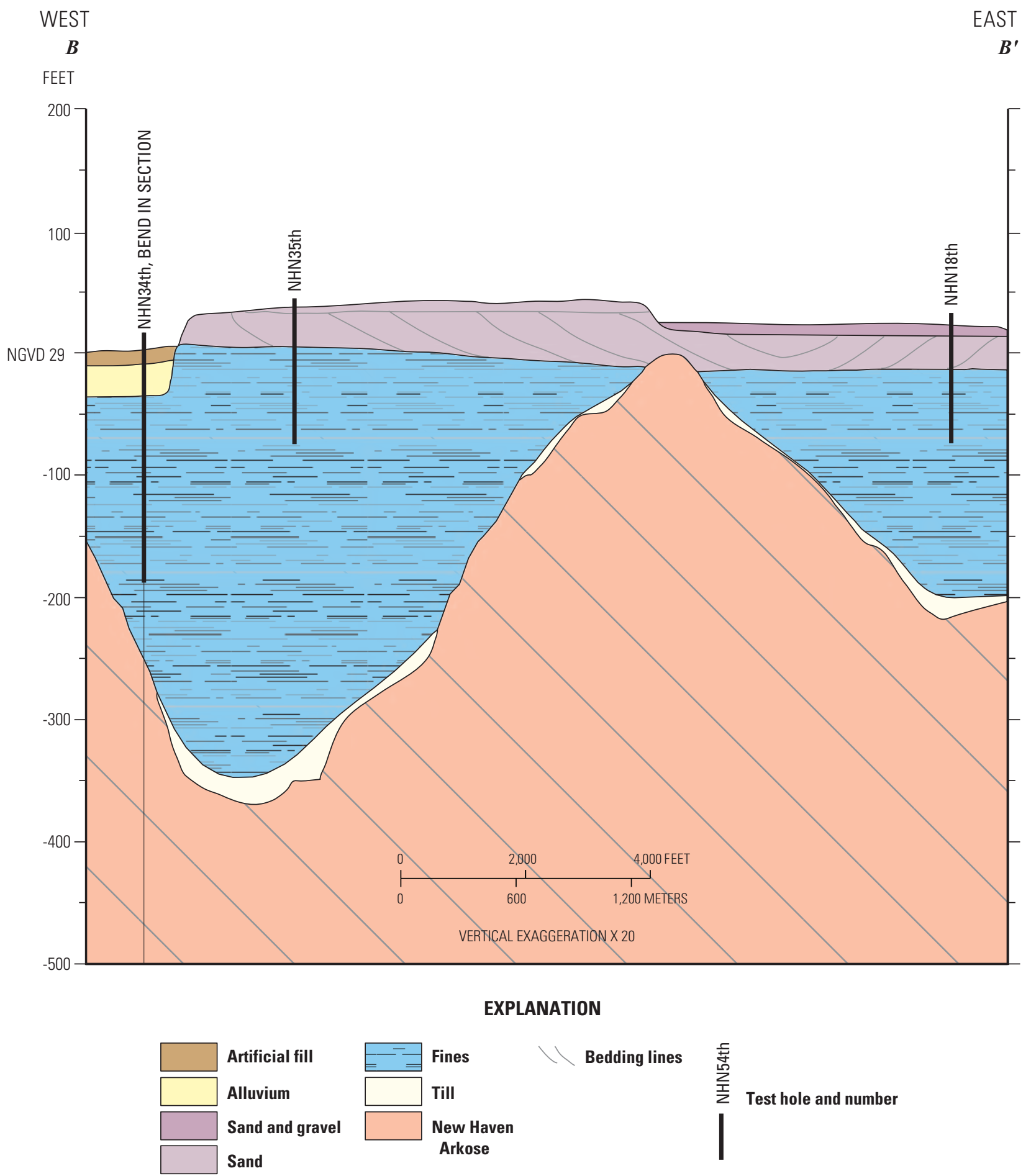

Figure 1-4. Cross sections $A, A-A^{\prime}$ and $B, B-B^{\prime}$ of figure 1-1.-Continued 


\section{References}

Bard, E., Hamelin, B., Fairbanks, R.G., and Zindler, A., 1990, Calibration of the C-14 timescale over the past 30,000 years using mass spectrometric U-Th ages from Barbados corals: Nature, v. 345, p. 405-410.

Fairbanks, R.G., 1989, A 17,000-year glacio-eustatic sea level record; influence of glacial melting rates on the Younger Dryas event and deep-ocean circulation: Nature, v. 342, p. 637-642.

Lewis, R.S., and Stone, J.R., 1991, Late Quaternary stratigraphy and depositional history of the Long Island Sound basinConnecticut and New York: Journal of Coastal Research, v. 11, p. 1-23.

Nydick, K.R., Bidwell, A.B., Thomas, E., and Varekamp, J.C., 1995, A sea-level rise curve from Guilford, Connecticut, USA: Marine Geology, v. 124, no. 1-4, p. 137-159.

Rodgers, John (compiler), 1985, Bedrock geological map of Connecticut: Connecticut Geological and Natural History Survey, Natural Resources Atlas Series Map, 2 sheets, scale 1:125,000.

Smith, N.D., and Ashley, G., 1985. Proglacial lacustrine environment in Ashley, G.M., Shaw, J., and Smith, N.B. (eds.), Glacial Sedimentary Environments: Society of Economic Paleontologists and Mineralogists, short course no. 16, p. 135-216.

Stone, J.R., Schafer, J.P., London, E.H., DiGiacomo-Cohen, Mary, Lewis, R.S., and Thompson, W.B., 2005, Quaternary geologic map of Connecticut and Long Island Sound basin, with a section on sedimentary facies and morphosequences of glacial meltwater deposits by B.D. Stone: U.S. Geological Survey Scientific Investigations Map 2784, 2 sheets, one pamphlet, scale $1: 125,000$.

Stone, J.R., Schafer, J.P., London, E.H., and Thompson, W.B., 1992, Surficial materials map of Connecticut: U.S. GeologicalSpecial Map, 2 sheets, scale 1:125,000.

Stone, J.R., Stone, B.D., and Lewis, R.S., 1985, Late Quaternary deposits of the southern Quinnipiac-Farmington lowland and Long Island Sound basin - Their place in a regional stratigraphic framework, Trip C6 in Tracey, R.J., ed., Guidebook for fieldtrips in Connecticut and adjacent areas of New York and Rhode Island, New England Intercollegiate Geological Conference 77th Annual Meeting, New Haven, Conn., October 4, 5, and 6, 1985: Connecticut Geological and Natural History Guidebook 6, p. 535-575.

Van de Plassche, O., Van der Borg, K., and de Jong, A.F.M., 1998, Sea level-climate correlation during the past 1400 years: Geology v. 26, no. 4, p. 319-322.

Varekamp, J.C., Thomas, E., and Van de Plassche, O., 1992, Relative sea-level rise and climate change over the last 1500 years: Terra Nova, v. 4, no. 3, p. 293-304. 


\section{Appendix 2. Development of Preliminary Groundwater-Flow Model}

\section{Contents}

Description of Flow Model and Model Assumptions..............................................................38

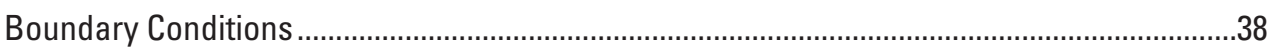

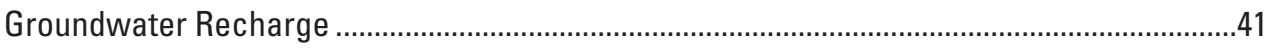

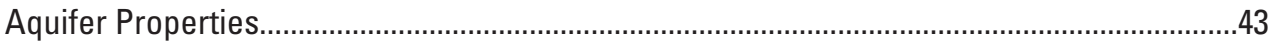

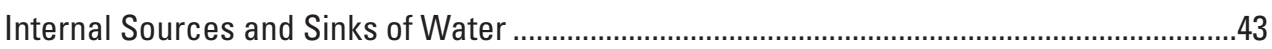

Comparison of the Model to Observations, Sensitivity of Selected Parameters, and

Water Budget.............................................................................................................4

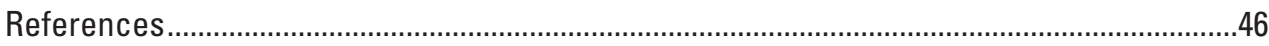

\section{Figures}

2-1. Map showing model grid, boundaries, simulated surface-water bodies, and locations of cross sections through model layers and wells where water-level measurements were made in the New Haven, Connecticut, study area..

2-2. Cross sections $A-A^{\prime}$ and $B-B^{\prime}$, showing vertical and horizontal discretization of model layers, and hydraulic properties assigned to aquifer materials in the model of the New Haven, Connecticut, study area

2-3. Map showing estimated impervious cover for each active model cell, New Haven, Connecticut

2-4. Graph showing simulated and mean measured hydraulic head 2009-2010, New Haven, Connecticut.

\section{Tables}

2-1. Estimates of recharge and hydraulic conductivity used in finite difference groundwater-flow model, New Haven, Connecticut.

2-2. Model calculated hydrologic budget, and analysis of the effects of changes to selected model parameters on hydrologic budget and simulated water levels. 


\section{Appendix 2. Development of Preliminary Groundwater-Flow Model}

\section{Description of Flow Model and Model Assumptions}

To test hypotheses regarding the effects of the rise in sea level on groundwater levels, the study used a three-dimensional, finite-difference groundwater-flow model. The preliminary MODFLOW groundwater-flow model (Harbaugh and others, 2000) for the New Haven area uses a finite-difference grid with 80 rows and 70 columns. All cells in the model are 400 by $400 \mathrm{ft}$ (fig. 2-1), and the model has three layers (fig. 2-2). The uppermost two layers represent the unconsolidated surficial deposits, except in areas with till as the surficial deposit. In these areas, bedrock and till were treated as a combined unit with a single hydraulic conductivity and a recharge rate equivalent to that for till. The boundary condition for the bottom of the model is a specified-flow boundary with rate set equal to zero, because groundwater flow in fractures in deep bedrock is assumed to be minimal. Other recent studies in Connecticut have shown that model results have been relatively insensitive to the depth of the bedrock beneath glacial deposits (Starn and Brown, 2007). Therefore, the lowermost layer (layer 3) simulates the bedrock aquifer to a depth of $300 \mathrm{ft}$ below the bedrock surface. The top layer of the model is assumed to be unconfined (water-table aquifer). Layers 2 and 3 are assumed to be confined and to have fixed transmissivity.

The preliminary model is a steady-state simulation that was compared to mean measurements of a limited set of observations of groundwater levels made during 2009-2010 at 11 wells. The assumption of a steady state condition was adequate for the purpose of this model. In future updated simulations, this assumption will require justification, or the use of a transient model. There is some evidence based on long-term water levels that the area was not in a steady state as recently as the mid-1970s. (http://nwis.waterdata.usgs.gov/ct/nwis/gwlevels/?site_no=411805072545801\&agency_cd=USGS\&amp). Water-level data show the gradual end of a series of major groundwater withdrawals as reported by Brown (1928), and a subsequent rise in water levels in the aquifer. Currently (2011), no long-term groundwater withdrawals are known to have been reported for the study area, although construction projects have required some temporary dewatering (R.H. Miller, City Engineer, and New Haven, Conn., written commun., April 13, 2011). Rise in sea level on the Connecticut coast, although slow, is occurring, indicating slow change in the altitude of Long Island Sound relative to the Connecticut coast (National Oceanic and Atmospheric Administration, 2011).

Horizontal hydraulic conductivity and recharge were adjusted by trial and error until the best match with measured water levels was obtained. Information on groundwater discharge to rivers or to Long Island Sound was unavailable and will require further research. Information on discharge from this groundwater-flow system would constrain recharge rates and eliminate some sources of uncertainty.

\section{Boundary Conditions}

The top of layer 1 is the water table and was simulated as a specified-flow boundary, the value of which was set to the mean annual groundwater recharge. Recharge rates used in this simulation are "effective" recharge rates that include the effects of groundwater evapotranspiration.

Model boundaries were based on the hydrologic boundaries of the New Haven study area (figs. 2-1, 2-2). The southern boundary of the model is New Haven Harbor; it was simulated using a constant-head boundary with altitude set to current (2011) sea level. In a scenario of future rise in sea level, the constant heads were adjusted to the projected change in sea level of $3 \mathrm{ft}$. The model is bounded on the west by the West River and on the east by the Mill River. These rivers were treated as headdependent boundaries, and they were simulated with the RIVER package in MODFLOW-2000. Field measurements during the study determined that these rivers were under tidal influence even though both rivers have tide gates that allow more flow downstream than flow upstream. Therefore, the altitudes of the water surface in these rivers were set to current (2011) sea levels. One segment of the northern boundary of the model includes the stream draining from Beaver Ponds Park. This stream/pond also was simulated as a head-dependent flow boundary using the DRAIN package in MODFLOW-2000. The remaining segment of the northern boundary of the model is simulated as a no-flow boundary that generally coincides with the boundaries of local drainage basins. The lower boundary of the model is a no-flow boundary $300 \mathrm{ft}$ below the surface of the bedrock. The altitude of the bedrock surface was determined using the map by Haeni and Sanders (1974). 

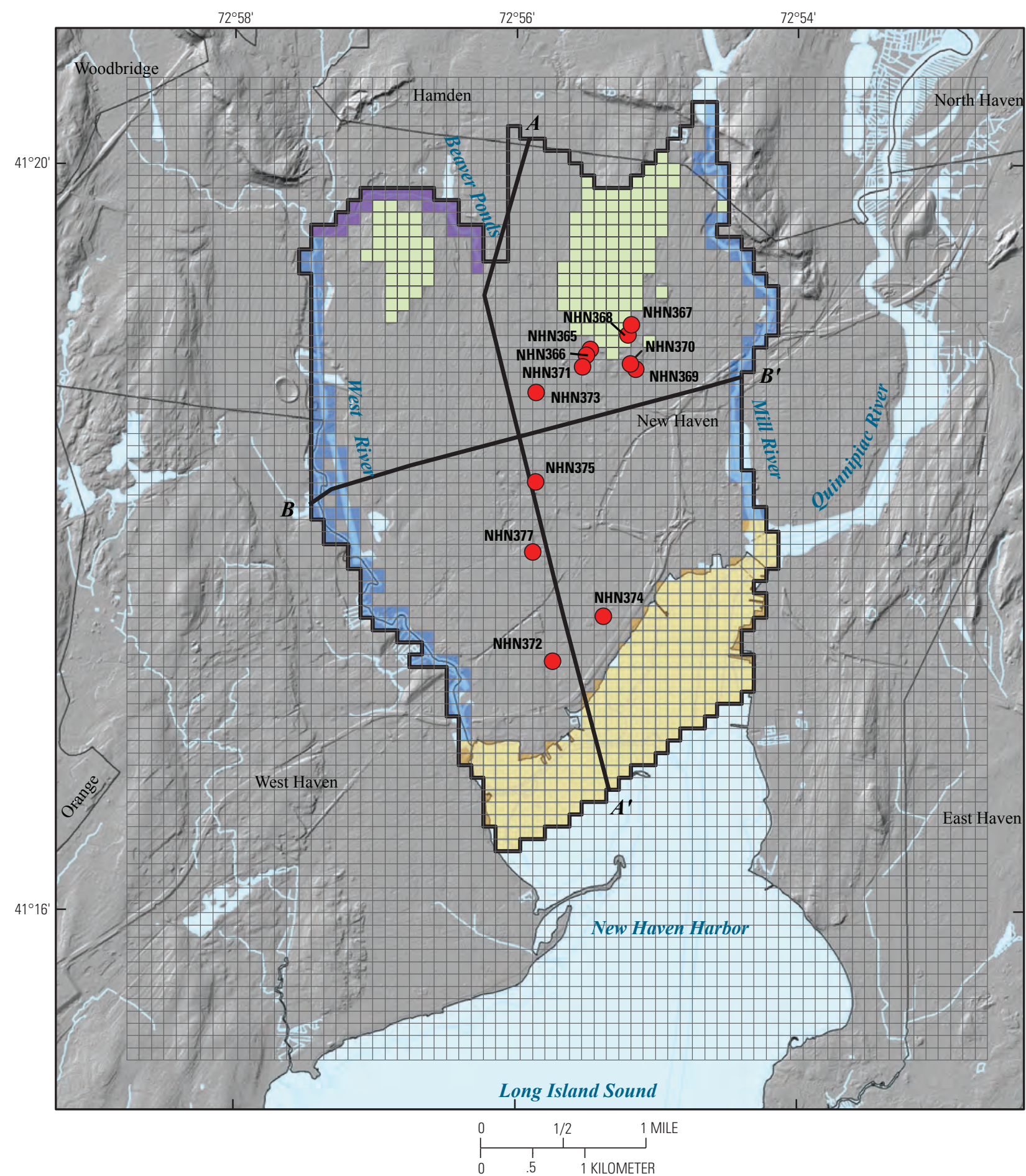

EXPLANATION

$\begin{aligned} & \text { Cells with till as surficial material (all other } \\ & \text { active cells assigned as coarse-grained } \\ & \text { glacial stratified deposits) }\end{aligned}$
$\begin{aligned} & \text { Cell containing simulated drain } \\ & \square \quad \text { Active model area }\end{aligned}$
$\begin{aligned} & \text { Cell containing simulated river } \\ & \square\end{aligned}$

Figure 2-1. Model grid, boundaries, simulated surface-water bodies, and locations of cross sections through model layers and wells where water-level measurements were made in the New Haven, Connecticut, study area. 

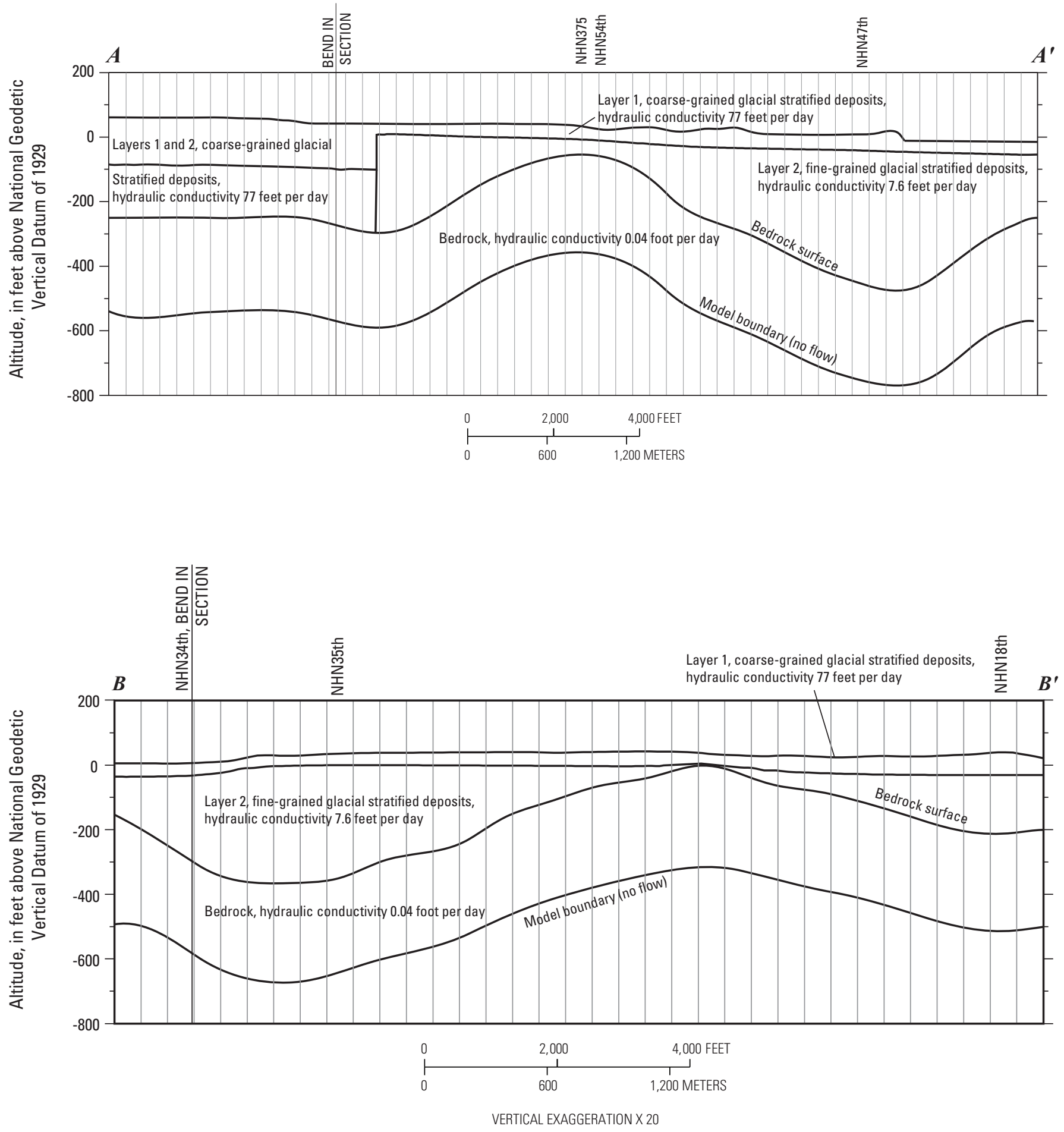

Figure 2-2. Cross sections A-A' and B-B', showing vertical and horizontal discretization of model layers, and hydraulic properties assigned to aquifer materials in the model of the New Haven, Connecticut, study area. Lines of section shown on figure 2-1. 


\section{Groundwater Recharge}

Groundwater recharge rates were assigned to the model on the basis of surficial geology and percent of pervious areas within each model cell. Initial values of recharge for glacial stratified deposits were based on values previously used in studies in Connecticut. A recharge rate of $22 \mathrm{in} / \mathrm{yr}$ was used in a study of the Pomperaug Basin (Lyford and others, 2007). The valley fill deposits of the Pomperaug Basin are similar to those in New Haven. This recharge rate also is similar to those calculated using methods described by Mazzaferro and others (1979). Values of recharge and hydraulic conductivity were then adjusted to obtain the closest match of simulated water levels to the average measured water levels. The optimal recharge rates and hydrologic parameters that provided the minimum difference between observed and simulated water levels are shown in table 2-1.

This simulation assumed that impervious areas do not pass any recharge to the groundwater system. Percentages for impervious areas for each model cell were determined through use of an Impervious Surface Analysis Tool (ISAT) developed by Chabaeva and others (2004), with impervious surface coefficients for Connecticut developed by Prisloe and others (2003). The input to the tool is a series of interpreted LANDSAT images (Civco and others, 1998). The tool was run for each cell in the model using images from 2002. The mean impervious area for active cells in the model was 37 percent (fig. 2-3).

Impervious areas for the model were simulated with the use of a multiplier array that contained the fraction of pervious area ( 1 minus the fraction of impervious area) for each model cell. This array was then multiplied by the assigned recharge value for each cell. These recharge estimates are conservative, because not all impervious areas drain directly into watercourses. Water from rooftops and driveways may infiltrate onto lawns or other unpaved areas, and stormwater drainage from some areas may infiltrate to the water table if the stormwater is discharged to retention basins or is allowed to flow onto pervious areas.

Recharge to groundwater in urban settings can be very complex due to the presence of these impervious surfaces and different types of underground utilities (Lerner, 2002). Further information is needed to understand the potential effects of leaks in water and sewer lines (sanitary and storm sewers), as well as the implications of current Best Management Practices for stormwater that encourage the infiltration of stormwater to improve water quality. Information on rates of groundwater discharge may be useful in improving estimates of recharge.

Table 2-1. Estimates of recharge and hydraulic conductivity used in finite difference groundwater-flow model, New Haven, Connecticut.

[na, not applicable]

\begin{tabular}{|c|c|c|c|c|}
\hline Geologic material & Layer & $\begin{array}{l}\text { Hydraulic conductivity, } \\
\text { in feet per day, or ratio } \\
\text { (dimensionless) }\end{array}$ & $\begin{array}{l}\text { Recharge rate, } \\
\text { in inches } \\
\text { per year }\end{array}$ & $\begin{array}{l}\text { Values from other reports } \\
\text { (hydraulic conductivity, in feet } \\
\text { per day, ratio, dimensionless) }\end{array}$ \\
\hline Coarse-grained glacial stratified deposits & 1 and 2 & 77 & 25 & $\begin{array}{l}9.8-171 \\
\quad \text { Starn and Brown (2007) }\end{array}$ \\
\hline Fine-grained glacial stratified deposits & 2 & 7.6 & na & $\begin{array}{l}7.5 \\
\text { Starn and Brown (2007) }\end{array}$ \\
\hline Glacial till & 1 and 2 & Not simulated & 9.9 & \\
\hline Arkosic bedrock/thin till-covered arkosic bedrock & 3 & 0.043 & na & $\begin{array}{l}0.09-4.9 \\
\quad \text { Starn and Brown (2007) }\end{array}$ \\
\hline $\begin{array}{l}\text { Ratio of horizontal to vertical hydraulic conductivity } \\
\text { in coarse-grained glacial stratified deposits }\end{array}$ & 1 and 2 & 10 & na & $\begin{array}{l}1-10 \\
\quad \text { Stone and others }(2004)\end{array}$ \\
\hline $\begin{array}{l}\text { Ratio of horizontal to vertical hydraulic conductivity } \\
\text { in fine-grained glacial stratified deposits }\end{array}$ & 2 & 50 & na & $\begin{array}{l}10-100 \\
\text { Stone and others }(2004)\end{array}$ \\
\hline
\end{tabular}




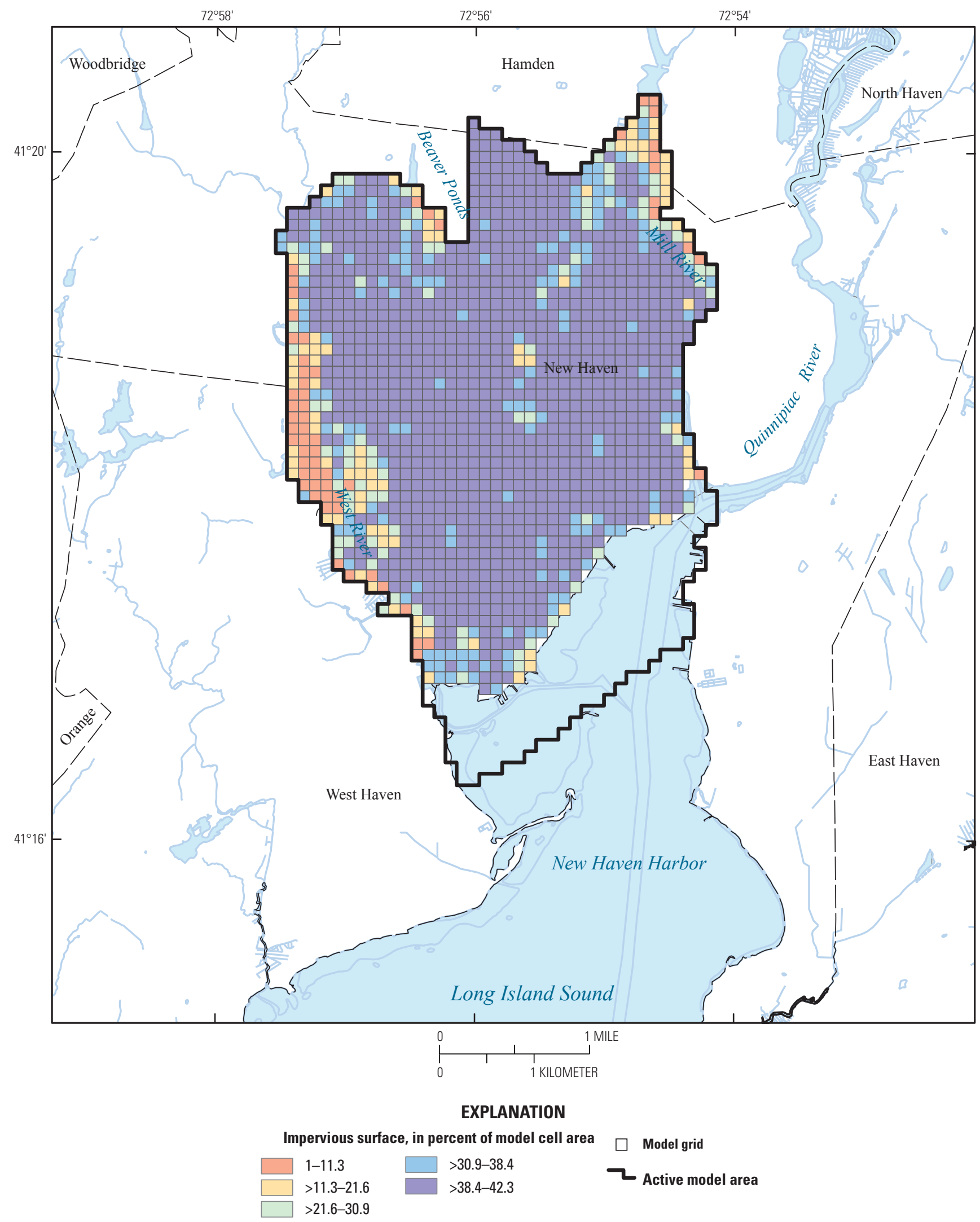

Figure 2-3. Estimated impervious cover for each active model cell, New Haven, Connecticut. 


\section{Aquifer Properties}

Aquifer properties (table 2-1) were assigned on the basis of the generalized surficial geology of the New Haven area (see appendix 1). Layer 1 in areas of glacial stratified deposits was assumed to contain coarse-grained deposits, based on a description of the depositional environment and test-hole data in Mazzaferro (1973) and on descriptions of the aquifer material in Mazzaferro and others (1979). Layer 1 averages $59 \mathrm{ft}$ in thickness (including the unsaturated zone). Layer 1 generally represents a coarser layer that overlies a finer layer (layer 2), except in the northernmost region of the study area, where it represents the top layer of 2 coarse-grained layers. The value of hydraulic conductivity simulated for the coarse-grained deposits was 77 feet per day (ft/d), which is in the range of a fine to coarse sand. The ratio of horizontal to vertical hydraulic conductivity $\left(\mathrm{K}_{\mathrm{h}} / \mathrm{K}_{\mathrm{v}}\right)$ was assumed to be 10:1 (Stone and others, 2004).

There are substantial areas of filled land near the New Haven shoreline. The upper layer of the model in these areas was assumed to have hydraulic characteristics similar to those of the coarse-grained glacial stratified deposits. Limited descriptions of the fill materials in this area include medium sand (NHN47th), medium sand, and cinders (NHN33th), and refuse (NHN6th). Other well and testhole data indicate the presence of salt marsh deposits (NHN2th) (logs in Mazzaferro, 1973).

Layer 2 averages $186 \mathrm{ft}$ in thickness and represents fine-grained glaciolacustrine bottomset beds. The top of layer 2 was determined through analysis of testhole and well data, and through the description of the geologic model in maps of surficial geology (Stone and others, 1992) (J.R. Stone, U.S. Geological Survey, written commun., May 2011). The geologic map by Stone and others (1992) dictates that fine-grained bottomset beds should exist in the northernmost parts of the study area. Testhole data (NHN49th, and NHN50th (Mazzaferro, 1973)) do not confirm these assumptions. The fine-grained layer was therefore not simulated in the northern part of the study area, and coarse materials with properties described above for layer 1 were simulated for this part of layer 2. A hydraulic conductivity value of $7.6 \mathrm{ft} / \mathrm{d}$ was assigned to layer 2 . This value is consistent with values of material ranging from clay to very fine sand in southern New England as reported by Mazzaferro and others (1979). The $\mathrm{K}_{\mathrm{h}} / \mathrm{K}_{\mathrm{v}}$ in these fine-grained materials was assumed to be 50:1 (Stone and others, 2004). In areas where till is the surficial deposit, the till and the underlying arkosic bedrock were simulated as one unit (across three layers) because of the minimal thickness of till. The value of hydraulic conductivity $(0.04 \mathrm{ft} / \mathrm{d})$ was assigned on the basis on trial and error adjustment. This value is in the range reported by Lyford and others (2007, table 6.1), and by Starn and Brown (2007), and used by Mullaney (2007) (0.1 ft/d for arkosic bedrock). The bedrock was assumed to have $\mathrm{a} \mathrm{K}_{\mathrm{h}} / \mathrm{K}_{\mathrm{v}}$ of 1:1.

\section{Internal Sources and Sinks of Water}

New Haven had been the center of historical pumping for industries during the early 20th century. Since the 1970s, pumping was curtailed in the city. The present simulation assumes that there are no groundwater withdrawals from the study area (R.H. Miller, City Engineer, New Haven, Conn., written commun., April 13, 2011). It was assumed that the vertical hydraulic conductivity of the streambeds (Mill and West Rivers) was $1 \mathrm{ft} / \mathrm{d}$, the streambed was 1-ft thick, and the stream was 1-ft deep. The width of the streams in each model cell was estimated from topographic maps. The stream draining Beaver Ponds Park was simulated as a drain. The main difference between the STREAM package and the DRAIN package in MODFLOW is that the DRAIN package limits the discharge of water to time periods when the head in the aquifer is above the drain. The conductance of the drain was simulated as equivalent to a stream with a bed thickness of $1 \mathrm{ft}$, width of $10 \mathrm{ft}$, and a streambed hydraulic conductivity of $1 \mathrm{ft} / \mathrm{d}$.

\section{Comparison of the Model to Observations, Sensitivity of Selected Parameters, and Water Budget}

The water levels simulated by the groundwater-flow model were compared to mean water-level measurements made at 11 wells during October 2009-June 2010 (fig. 2-4). Values of hydraulic conductivity and recharge were adjusted upward and downward until the average water-level error was minimized. The average residual for the 11 wells was $-0.079 \mathrm{ft}$ and the range of the absolute residuals was from 0.28 to $4.3 \mathrm{ft}$. There were no water-level observations in some areas that were simulated, including the western side of New Haven in the glacial-stratified deposits, and on the two thin, till-covered bedrock hills at the northern limits of the model. Model accuracy in these unmonitored areas is unknown. Additional water-level data in these areas would improve future models. Simulated water levels were near or above land surface on the hill in the northeast part of the model area. Based on the observations of water levels, a steep gradient exists between wells NHN370 and NHN369. The gradient at this location was not simulated accurately because of the discretization chosen for this model, or a geohydrologic change exists that is not represented in the model. These wells are close to the contact between the stratified drift and the till-covered bedrock hill in the northeast corner of the model area.

The sensitivity of selected model parameters was tested by trial and error and the water budget was evaluated for each change to the model for differences in inputs and outputs of water (table 2-2). The sum of squared residuals was used as a 


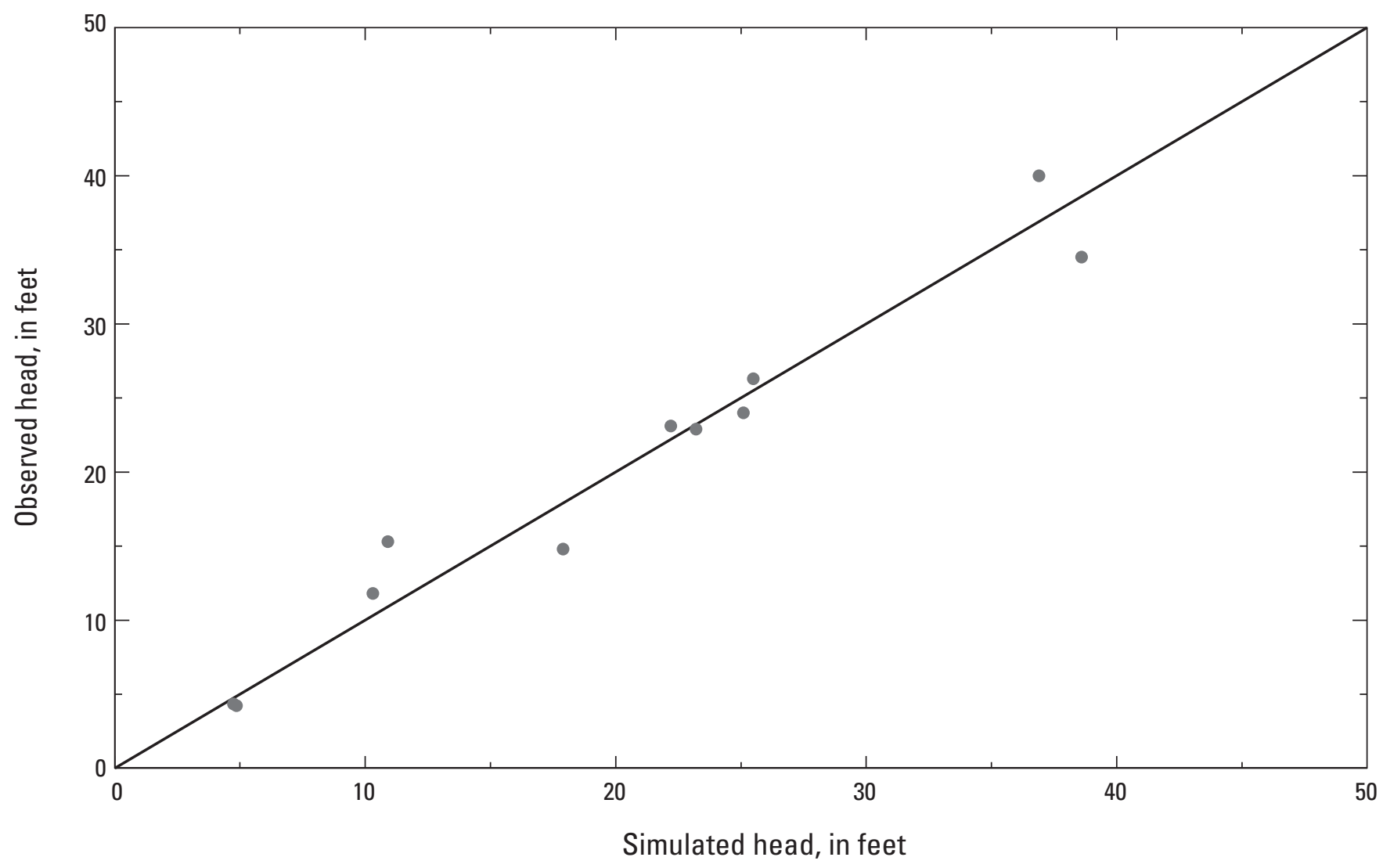

Figure 2-4. Simulated and mean measured hydraulic head 2009-2010, New Haven, Connecticut.

measure of fit to model observations, which were limited to water-level measurements. Adjustments were made to the following parameters in the model: (1) depth to bottom of model (thickness of layer 3); (2) hydraulic conductivity of coarse-grained glacial stratified deposits; (3) hydraulic conductivity of fine-grained deposits in layer 2; (4) recharge; (5) river and drain conductance;

(6) $\mathrm{K}_{\mathrm{h}} / \mathrm{K}_{\mathrm{v}}$ of coarse-grained glacial stratified deposits; (7) $\mathrm{K}_{\mathrm{h}} / \mathrm{K}_{\mathrm{v}}$ of fine-grained deposits in layer 2; and (8) hydraulic conductivity of bedrock (table 2-2).

Simulated heads were most sensitive to changes in hydraulic conductivity of coarse-grained glacial stratified deposits and fine-grained deposits (layer 2), in recharge, and in hydraulic conductivity of the bedrock simulated in layer 3 . Simulated heads were generally insensitive to changes made to river bottom and to drain conductance, and to the $\mathrm{K}_{\mathrm{h}} / \mathrm{K}_{\mathrm{v}}$. Sensitivity of simulated heads may be biased due to the limited number and spatial distribution of water-level observation sites.

River leakage from the model was generally insensitive to changes in the parameters described here, except for upward or downward changes to recharge. Leakage from the drain in the model (simulating the stream draining the Beaver Ponds Park) was relatively insensitive to changes in parameters, but flow increased when the hydraulic conductivity of the coarse-grained glacial stratified deposits was decreased, and flow decreased when the hydraulic conductivity of the coarse-grained glacial stratified deposits was increased. Leakage from the drain also was sensitive to changes in the hydraulic conductivity of the finegrained layer simulated in layer 2; this indicates that having discharge measurements from the stream draining the Beaver Ponds Park may be useful in enhancing and calibrating future models.

A qualitative analysis of parameter correlation indicated that the parameters used in this model may be correlated to one another (for example, recharge and hydraulic conductivity) with the implication being that changes in one are equivalent to changes in another. Additional data collection as described in the limitations section of the report, particularly, measurement of discharge of water from the aquifer may help reduce this correlation. 
Table 2-2. Model calculated hydrologic budget, and analysis of the effects of changes to selected model parameters on hydrologic budget and simulated water levels.

$\left[\mathrm{ft}^{3} / \mathrm{s}\right.$, cubic feet per second; $\mathrm{ft}$, feet; $\%$, percent]

\begin{tabular}{|c|c|c|c|c|c|c|}
\hline \multirow[b]{2}{*}{ Model change } & \multirow{2}{*}{$\begin{array}{c}\text { Sum of } \\
\text { squared } \\
\text { residuals }{ }^{1}\end{array}$} & \multicolumn{2}{|c|}{ Model inputs } & \multicolumn{3}{|c|}{ Model outputs } \\
\hline & & $\begin{array}{c}\text { River leakage, } \\
\text { in } \mathrm{ft}^{3} / \mathrm{s}\end{array}$ & $\begin{array}{c}\text { Recharge, } \\
\text { in } \mathrm{ft}^{3} / \mathrm{s}\end{array}$ & $\begin{array}{c}\text { River leakage, } \\
\text { in } \mathrm{ft}^{3} / \mathrm{s}\end{array}$ & $\begin{array}{c}\text { Drain leakage, } \\
\text { in } \mathrm{ft}^{3} / \mathrm{s}\end{array}$ & $\begin{array}{c}\text { Constant head, } \\
\text { in } \mathrm{ft}^{3} / \mathrm{s}\end{array}$ \\
\hline Original & 60.4 & 0.12 & 8.68 & 6.11 & 0.66 & 2.03 \\
\hline Layer 3 plus $200 \mathrm{ft}$ depth & 88.1 & 0.12 & 8.68 & 6.12 & 0.65 & 2.03 \\
\hline $\mathrm{K}_{\mathrm{h}}$ of glacial stratified deposits increased $25 \%$ & 77.2 & 0.13 & 8.68 & 6.24 & 0.54 & 2.03 \\
\hline $\mathrm{K}_{\mathrm{h}}$ of glacial stratified deposits decreased $25 \%$ & 118 & 0.10 & 8.68 & 5.97 & 0.78 & 2.04 \\
\hline $\mathrm{K}_{\mathrm{h}}$ of glacial stratified deposits decreased $50 \%$ & 422 & 0.08 & 8.68 & 5.79 & 0.89 & 2.07 \\
\hline $\mathrm{K}_{\mathrm{h}}$ of glacial stratified deposits increased $50 \%$ & 119 & 0.14 & 8.68 & 6.36 & 0.43 & 2.03 \\
\hline $\mathrm{K}_{\mathrm{h}}$ of fines in layer $2 / 10$ & 798 & $\begin{array}{l}\text { Model did not } \\
\text { converge }\end{array}$ & & & & \\
\hline $\mathrm{K}_{\mathrm{h}}$ of fines in layer $2 / 2$ & 125 & 0.06 & 8.68 & 6.03 & 0.78 & 1.94 \\
\hline $\mathrm{K}_{\mathrm{h}}$ of fines in layer $2 \times 1.5$ & 86.9 & 0.21 & 8.68 & 6.24 & 0.55 & 2.10 \\
\hline $\mathrm{K}_{\mathrm{h}}$ of fines in layer $2 \times 10$ & 1,150 & 0.40 & 8.68 & 6.50 & 0.00 & 2.58 \\
\hline Recharge to all active cells increased by $25 \%$ & 136 & 0.11 & 10.85 & 7.46 & 0.99 & 2.51 \\
\hline Recharge to all active cells decreased by $25 \%$ & 266 & 0.13 & 6.51 & 4.76 & 0.33 & 1.55 \\
\hline River and drain conductance $\times 2$ & 61.1 & 0.13 & 8.68 & 6.12 & 0.68 & 2.01 \\
\hline River and drain conductance $\times 10$ & 62.4 & 0.20 & 8.68 & 6.17 & 0.72 & 1.99 \\
\hline River and drain conductance $\times .1$ & 81.1 & 0.14 & 8.68 & 6.02 & 0.60 & 2.20 \\
\hline $\mathrm{K}_{\mathrm{h}} / \mathrm{K}_{\mathrm{v}}$ glacial stratified deposits $/ 10$ & 60.9 & 0.12 & 8.68 & 6.11 & 0.66 & 2.02 \\
\hline $\mathrm{K}_{\mathrm{h}} / \mathrm{K}_{\mathrm{v}}$ glacial stratified deposits $\times 10$ & 61.3 & 0.11 & 8.68 & 6.09 & 0.66 & 2.04 \\
\hline $\mathrm{K}_{\mathrm{h}} / \mathrm{K}_{\mathrm{v}}$ fines in layer $2 / 50$ & 69.7 & 0.20 & 8.68 & 6.37 & 0.64 & 1.88 \\
\hline $\mathrm{K}_{\mathrm{h}} / \mathrm{K}_{\mathrm{v}}$ fines in layer $2 \times 2$ & 61.1 & 0.11 & 8.68 & 6.06 & 0.67 & 2.07 \\
\hline $\mathrm{K}$ bedrock $\times 10$ & 881 & 0.14 & 8.68 & 6.21 & 0.57 & 2.04 \\
\hline $\mathrm{K}$ bedrock $\times 2$ & 305 & 0.12 & 8.68 & 6.12 & 0.65 & 2.03 \\
\hline $\mathrm{K}$ bedrock $/ 2$ & 1,040 & 0.12 & 8.68 & 6.11 & 0.66 & 2.03 \\
\hline \multicolumn{7}{|l|}{ Preliminary future scenarios } \\
\hline 3 - $\mathrm{ft}$ sea level rise & & 0.14 & 8.68 & 5.94 & 0.88 & 2.00 \\
\hline 3 -ft sea level rise plus $12 \%$ increase in recharge & & 0.14 & 9.68 & 6.55 & 1.03 & 2.23 \\
\hline
\end{tabular}

${ }^{1}$ Sum of squared residuals of difference in water level at 11 observation wells. 


\section{References}

Brown, J.S., 1928, Ground water in the New Haven area, Connecticut: U.S. Geological Survey Water-Supply Paper 540, 206 p.

Chabaeva, A.A., Civco, D.L., and Prisloe, S., 2004, Development of a population and land use based regression model to calculate the amount of imperviousness, in Proceedings of the annual ASPRS convention, Denver, Colorado, May 2004, University of Connecticut, 9 p., accessed September 10, 2009, at http://nemo.uconn.edu/tools/impervious_surfaces/pdfs/ Chabaeva_etal_2004.pdf.

Civco, D.L., Arnold, C.L., and Hurd, J.D., 1998, Land use and land cover mapping for the Connecticut and New York portions of the Long Island Sound Watershed: Office of Long Island Sound Programs, Connecticut Department of Environmental Protection, Research Project CWF 330-R Technical Completion Report [unpaginated].

Haeni, F.P., and Sanders, J.E., 1974, Contour map of the bedrock surface, New Haven-Woodmont quadrangle, Connecticut: U.S. Geological Survey Miscellaneous Field Studies Map MF-557-A, scale 1:24,000.

Harbaugh, A.W., Banta, E.R., Hill, M.C., and McDonald, M.G., 2000, MODFLOW-2000, The U.S. Geological Survey modular ground-water model-User guide to modularization concepts and the ground-water flow process: U.S. Geological Survey Open-File Report 00-92, 121 p.

Lyford, F.P., Carlson, C.S., Brown, C.J., and Starn, J.J., 2007, Hydrogeologic setting and ground-water flow simulation of the Pomperaug River Basin regional study area, Connecticut, section 6 of Paschke, S.S., ed., 2007, Hydrogeologic settings and ground-water flow simulations for regional studies of the transport of anthropogenic and natural contaminants to publicsupply wells—Studies begun in 2001: U.S. Geological Survey Professional Paper 1737-A, p. 6-1-6-26.

Mazzaferro, D.L., 1973, Hydrogeologic data for the Quinnipiac River basin, Connecticut: Connecticut Water Resources Bulletin $26,54 \mathrm{p}$.

Mazzaferro, D.L., Handman, E.H., and Thomas, M.P., 1979, Water resources inventory of Connecticut, part 8, Quinnipiac River basin: Connecticut Water Resources Bulletin 27, 88 p.

Mullaney, J.R., 2007, Nutrient loads and ground-water residence times in an agricultural basin in north-central Connecticut: U.S. Geological Survey Scientific Investigations Report 2006-5278, 45 p.

National Oceanic and Atmospheric Administration, 2011, Web page accessed November 28, 2011, at http://tidesandcurrents. noaa.gov/sltrends/sltrends_station.shtml?stnid $=8461490$.

Prisloe, M., Wilson, E.H., and Arnold, C., 2003, Final report—Refinement of population-calibrated land-cover-specific impervious surface coefficients for Connecticut: Nemo FY02 Workplan, DEP project 01-08, University of Connecticut, Middlesex County Extension Center, 20 p.

Starn, J.J., and Brown, C.J., 2007, Simulations of ground-water flow and residence time near Woodbury, Connecticut: U.S. Geological Survey Scientific Investigations Report 2007-5210, 45 p.

Stone, B.D., Stone, J.R., Masterson, J.P., and O'Leary, D.W., 2004, Integrating 3-D facies analysis of glacial aquifer systems with ground-water flow models: Examples from New England and the Great Lakes Region, USA, in Berg, R.C., Russell, Hazen, and Thorleifson, L. Harvey, eds., Three-dimensional geological mapping for groundwater applications - Geological Association of Canada, Mineralogical Association of Canada, 49th annual meeting, St. Catherines Ontario, Canada, Workshop Extended Abstracts: Illinois State Geological Survey, Open-File Series 2004-8, 100 p.

Stone, J.R., Schafer, J.P., London, E.H., and Thompson, W.B., 1992, Surficial materials map of Connecticut: U.S. Geological Special Map, 2 sheets, scale 1:125,000.

U.S. Geological Survey, 2011, Groundwater levels for Connecticut: U.S. Geological Survey, accessed November 28, 2011, at http://nwis.waterdata.usgs.gov/ct/nwis/gwlevels/?site_no=411805072545801\&agency_cd=USGS\&amp. 
Prepared by the Pembroke Publishing Service Center.

For more information concerning this report, contact:

Director

U.S. Geological Survey

Connecticut Water Science Center

101 Pitkin Street

East Hartford, CT 06108

dc_ct@usgs.gov

or visit our Web site at:

http://ct.water.usgs.gov 


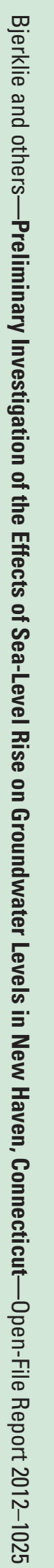

